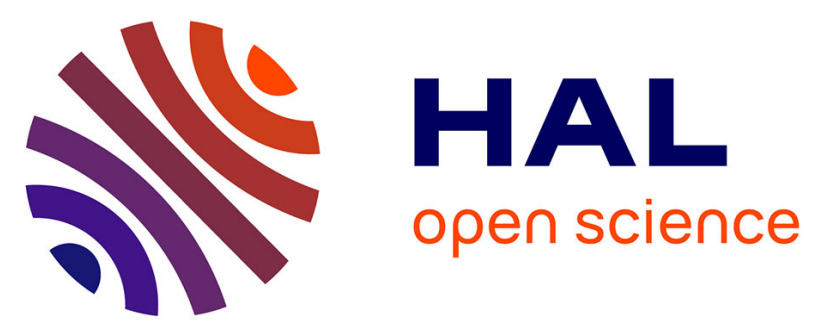

\title{
Vulnerability to reservoir reseeding due to high immune activation after allogeneic hematopoietic stem cell transplantation in individuals with HIV-1
}

Johanna M Eberhard, Mathieu Angin, Caroline Passaes, Maria Salgado, Valerie Monceaux, Elena Knops, Guido Kobbe, Björn Jensen, Maximilian Christopeit, Nicolaus Kröger, et al.

\section{To cite this version:}

Johanna M Eberhard, Mathieu Angin, Caroline Passaes, Maria Salgado, Valerie Monceaux, et al.. Vulnerability to reservoir reseeding due to high immune activation after allogeneic hematopoietic stem cell transplantation in individuals with HIV-1. Science Translational Medicine, 2020, 12 (542), pp.eaay9355. 10.1126/scitranslmed.aay9355 . pasteur-02870497

\section{HAL Id: pasteur-02870497}

\section{https://hal-pasteur.archives-ouvertes.fr/pasteur-02870497}

Submitted on 16 Jun 2020

HAL is a multi-disciplinary open access archive for the deposit and dissemination of scientific research documents, whether they are published or not. The documents may come from teaching and research institutions in France or abroad, or from public or private research centers.
L'archive ouverte pluridisciplinaire HAL, est destinée au dépôt et à la diffusion de documents scientifiques de niveau recherche, publiés ou non, émanant des établissements d'enseignement et de recherche français ou étrangers, des laboratoires publics ou privés. 


\section{Incomplete $\mathbf{T}$ cell reconstitution and vulnerability to reservoir}

2 reseeding after allogeneic hematopoietic stem cell transplantation in 3 individuals with $\mathrm{HIV}-1$

4

5

Johanna M. Eberhard ${ }^{1,2}$, Mathieu Angin ${ }^{3}$, Caroline Passaes ${ }^{3}$, Maria Salgado $^{4}$, Valerie Monceaux ${ }^{3}$, Elena Knops ${ }^{5}$, Guido Kobbe ${ }^{6}$, Björn Jensen ${ }^{7}$, Maximilian Christopeit ${ }^{8}$, Nicolaus Kröger ${ }^{8}$, Linos Vandekerckhove $^{9}$, Jon Badiola ${ }^{10}$, Alessandra Bandera ${ }^{11}$, Kavita Raj ${ }^{12}$, Jan van Lunzen ${ }^{1,13}$, Gero Hütter $^{14}$, Jürgen H.E. Kuball ${ }^{15}$, Carolina Martinez-Laperche ${ }^{16}$, Pascual Balsalobre ${ }^{16}$, Mi Kwon ${ }^{16}$, José L. Díez-Martín ${ }^{16}$, Monique Nijhuis ${ }^{15}$, Annemarie Wensing ${ }^{15}$, Javier Martinez-Picado ${ }^{4,17,18}$, Julian Schulze zur Wiesch ${ }^{1,2, \#}$ and Asier Sáez-Cirión ${ }^{3, \#}$; the IciStem study group

${ }^{1}$ Department of Medicine, Infectious Diseases Unit, University Medical Center Hamburg-Eppendorf, 20246 Hamburg, Germany.

${ }^{2}$ DZIF Partner Site (German Center for Infection Research), Hamburg - Lübeck - Borstel - Riems , Germany. ${ }^{3}$ Institut Pasteur, HIV, Inflammation and Persistence, 75015 Paris, France.

${ }^{4}$ AIDS Research Institute IrsiCaixa, 08916 Badalona, Spain.

${ }^{5}$ Institute of Virology, University of Cologne, 50935 Cologne, Germany.

${ }^{6}$ Department of Haematology, Oncology and Clinical Immunology, University Hospital Düsseldorf, 40225

Düsseldorf, Germany.

${ }^{7}$ Department of Gastroenterology, Hepatology and Infectious Diseases, University Hospital Düsseldorf, 40225

Düsseldorf, Germany.

${ }^{8}$ Department of Stem Cell Transplantation, University Medical Center Hamburg-Eppendorf, 20246 Hamburg, Germany.

${ }^{9}$ HIV Cure Research Center, Department of Internal Medicine, Faculty of Medicine and Health Sciences, Ghent University and Ghent University Hospital, B-9000 Ghent, Belgium.

${ }^{10}$ Hematology Department, Virgen de las Nieves University Hospital, 18014 Granada, Spain.

${ }^{11}$ San Gerardo Hospital, University of Milano-Bicocca, 20900 Monza, Italy.

${ }^{12}$ Department of Haematology, King's College Hospital, London SE5 9RS, UK.

${ }^{13}$ ViiV Healthcare, Brentford, Middlesex TW8 9GS, United Kingdom.

${ }^{14}$ Cellex, 01307D resden, Germany.

${ }^{15}$ University Medical Center Utrecht, 3584 CX Utrecht, Netherlands.

${ }^{16}$ Hospital Universitario Gregorio Marañón, Instituto de Investigación Sanitarias Gregorio Marañón, Universidad Complutense, 28007 Madrid, Spain.

${ }^{17}$ UVic-UCC, 08500 Vic, Spain.

${ }^{18}$ ICREA, 08010 Barcelona, Spain.

\#Equal contributors 
40 One sentence summary: Heterogenous immune reconstitution and priming of HIV-specific cells 41 post allo-HSCT in HIV-infected individuals . 


\section{Abstract:}

Allogeneic hematopoietic stem cell transplantation (allo-HSCT) is the only medical intervention which has led to an HIV cure. Whereas the size of the HIV reservoir sharply decreases after alloHSCT, the dynamics of the T-cell reconstitution has not been comprehensively described. We analyzed the activation and differentiation of $\mathrm{CD} 4^{+}$and $\mathrm{CD} 8^{+} \mathrm{T}$-cells, and the breadth and quality of HIV- and CMV-specific CD8 ${ }^{+}$T-cell responses in 16 patients with HIV who underwent alloHSCT (including 5 individuals who received cells from CCR $5 \Delta 32 / \Delta 32$ donors) to treat their underlying hematological malignancy and who remained on antiretroviral therapy (ART). We found that reconstitution of the T-cell compartment was slow and heterogeneous with an initial expansion of activated $\mathrm{CD} 4^{+} \mathrm{T}$-cells that preceded the expansion of $\mathrm{CD} 8^{+} \mathrm{T}$-cells; full immune reconstitution was not achieved after allo-HSCT. Although HIV-specific CD8 ${ }^{+}$T-cells disappeared immediately after allo-HSCT, weak ex vivo $\mathrm{HIV}$-specific $\mathrm{CD} 8^{+} \mathrm{T}$-cell responses were detectable several weeks after transplant, and could still be detected at the time of full T-cell chimerism, indicating that de novo priming, and hence antigen exposure, occurred during the time of T-cell expansion. These HIV-specific T-cells had limited functionality compared to CMVspecific $\mathrm{CD}^{+} \mathrm{T}$-cells, and persisted years after allo-HSCT. In conclusion, immune reconstitution was slow, heterogeneous and incomplete and coincided with de novo detection of weak HIVspecific T-cell responses. The initial short phase of high T-cell activation, in which HIV antigens were present, may constitute a window of vulnerability for the reseeding of viral reservoirs, emphasizing the importance of maintaining ART directly after allo-HSCT. 


\section{Introduction}

The Berlin patient is the only HIV-infected individual who is considered to be HIV cured after he underwent allogeneic hematopoietic stem cell transplantation (allo-HSCT) with cells of an HLAidentical donor who was CCR5 $\Delta 32$ homozygous (1). CCR5 $\Delta 32$ homozygosity impairs cell surface expression of CCR 5 and confers protection towards HIV-1 strains using CCR5 as entry co-receptor $(2,3)$. Recently, a second case of durable HIV remission after allo-HSCT with a CCR5 $\Delta 32$ homozygous graft has been described in a patient from London, who did not show signs of HIV rebound 30 months after stopping antiretroviral therapy $(\operatorname{ART})(4,5)$. Whereas HIV reservoirs stably persist even after decades of efficient ART (O), allo-HSCT in people with HIV is accompanied by a rapid and drastic decrease of the frequency of HIV-infected cells in blood and different tissues often to undetectable amounts (7), independent of engraftment with CCR5 $\Delta 32$ or CCR5 wildtype (wt) stem cells (8). Therefore, allo-HSCT, although not scalable, theoretically offers an opportunity to achieve HIV cure in HIV-infected patients who require such intervention to treat their underlying hematological cancer.

However, other HIV-infected individuals who interrupted their ART after receiving CCR5 $\Delta 32$ heterozygous (9), homozygous $(10)$ or wildtype $(9,11,12)$ grafts, have shown an eventual resurgence of HIV replication despite having undetectable virologic reservoir markers while on ART, and being able to transiently control HIV replication after treatment discontinuation. Therefore, the clinical, immunological and virologic factors associated with durable HIV remission in HIV-infected individuals undergoing allo-HSCT remain unclear. The cases of the Berlin and London patients emphasize the critical importance of CCR5 32 homozygous transplants to impose a strong barrier for HIV dissemination upon engraftment (13). At this point, 
it is not clear whether a CCR5 32 homozygous transplant status is an essential condition to achieve HIV cure, but immune responses in allo-HSCT HIV-infected individuals may not be sufficient to counteract the spread of HIV from any remaining residual viral reservoir. Reactivation of different latent viral infections (e.g. cytomegalovirus (CMV), hepatitis B virus (HBV), EpsteinBarr virus (EBV)) are common among individuals receiving allo-HSCT (14-16), and different aspects of the allo-HSCT (e.g. conditioning, immunosuppressive drugs, graft-vs-host disease, delayed immune reconstitution) are associated with flawed development of virus-specific immune responses and enhanced morbidity and mortality related to viral infections (17-19). Despite their evident interest in the search for an HIV cure, the exceptionality of cases of HIV-infected individuals undergoing allo-HSCT $(1,4,7,10,12,20-22)$ has precluded detailed comprehensive immunological studies during and following allo-HSCT in groups of such individuals.

Since 2014, the IciStem consortium (International Collaboration to guide and investigate the potential for HIV cure by Stem Cell Transplantation) has followed HIV-infected individuals who receive allo-HSCT for hematologic conditions in an observational study (www.icistem.org) (7). IciStem longitudinally collects samples and clinical data of the participants and generates comprehensive immunological and virologic data to elucidate correlates of HIV persistence. In the current study we describe the immunological reconstitution of the T-cell compartment and the breadth and functionality of HIV-specific T-cell responses of 16 IciStem participants who underwent allo-HSCT. 


\section{Results}

\section{Study population}

Sixteen IciStem participants from eight medical centers in six countries were included. A summary of the participants' clinical and hematologic, as well as virologic details are shown in Table $\mathbf{1}$ and Table S1, respectively. The most frequent hematologic malignancies of the participants were nonHodgkin lymphoma $(\mathrm{n}=6)$ and acute myeloid leukemia $(\mathrm{n}=5)$. The majority of the participants received an allogeneic hematopoietic stem cell graft from the peripheral blood of HLA-matched unrelated or related donors $(\mathrm{n}=8)$ or HLA-haploidentical siblings or relatives $(\mathrm{n}=5)$. IciS-01, IciS04 and IciS-05 received a cord blood graft. All patients were maintained on ART following alloHSCT. Individual HSCT conditioning and ART regimens are described in Table $\mathbf{1}$ and Table S1 respectively. The HLA-alleles of every participant and their respective donor are depicted in Table S2.

Nine out of $16(56 \%)$ participants (including two who received cells from CCR $5 \Delta 32 / \Delta 32$ donors) were alive and in active follow-up at the time of this report (Fig. S1). Seven participants (44\%, including three who received hematopoietic stem cells from CCR $5 \Delta 32 / \Delta 32)$ died due to relapse of their primary disease or complications associated with allo-HSCT (median 3 months after alloHSCT). Overall, the mortality rate of the patients in this cohort was not significantly different from that observed in uninfected individuals with similar malignancies undergoing allo-HSCT $(23,24)$. Although this high mortality rate is in agreement with previous reports $(25,26)$, some of the surviving patients in our study were included retrospectively which may affect our estimations.

All the patients had detectable cell-associated HIV-DNA at baseline (median of 1458 HIV LTR copies/million CD4+ T-cells). Independently of the donor-CCR5 genotype, the cell-associated 
HIV-DNA dropped, and could not be detected for all but two patients (IciS-01, who had $453 \mathrm{HIV}$ LTR copies/million CD4+ T-cells 45 months after allo-HSCT (7) and IciS-20 who had 186 HIV LTR copies/million CD4 ${ }^{+}$T-cells 8 months after allo-HSCT) at the last follow up post allo-HSCT (range: 2-88 months), in agreement with the profound decrease in viral reservoir markers that we have previously reported in a subset of the patients analyzed here (8).

All study participants had undetectable viral loads by clinical standards before and after alloHSCT. However, eight of the nine patients with samples available at the baseline had detectable ultrasensitive viral loads (usVL) before allo-HSCT (median 38 HIV-1 RNA copies/ml of plasma). The frequency progressively decreased until virtually nothing could be detected 7 months after allo-HSCT ( 0.8 HIV RNA copies/ml of plasma for 1 out of 9 patients tested at this time point, undetectable for the others). However, during the initial 6 months low level viremia (median 3 HIV RNA copies/ml of plasma) could be detected in $57 \%$ to $67 \%$ of patients with available samples.

\section{Partial reconstitution of the T-cell compartment after allo-HSCT}

We aimed to characterize the kinetics of T-cell immune reconstitution and T-cell activation and differentiation in our cohort before and after allo-HSCT. Frozen peripheral blood mononuclear cells (PBMC) were available for immunological analysis of bulk and HIV-specific T-cells in nine participants before allo-HSCT and up to month 27 after allo-HSCT; and in 7 other participants samples were collected at various time points between month 6 and 88 after allo-HSCT (fig. S1).

The study participants were treated with chemotherapy regimens for their respective underlying hematological malignancy and showed relatively low $\mathrm{CD}^{+}{ }^{+} \mathrm{T}$-cell counts (median 490 cells $/ \mu 1$ of 
blood) (Table S3) and an inverted CD4/CD8 ratio $<1$ just before allo-HSCT (Fig. 1A). As expected, a generalized severe lymphopenia was observed during the initial 2-6 weeks post-HSCT, with some prevailing $\mathrm{CD} 4^{+} \mathrm{T}$-cells in circulation in almost total absence of $\mathrm{CD} 8^{+} \mathrm{T}$-cells $(\mathbf{F i g} .1$ and fig. S2). Despite their initial lower frequency, a more rapid expansion of CD8 ${ }^{+} \mathrm{T}$-cells was observed in later weeks, similarly to what has been described for non-HIV infected subjects after allo-HSCT $(27,28)$. As a consequence, an inverse CD4/CD8 T-cell ratio was again observed for most patients around two months after allo-HSCT. In general, T-cell reconstitution and normalization of the CD4/CD8 T-cell ratio usually takes 1-2 years after allo-HSCT in HIVnegative individuals (29). In contrast inverse CD4/CD8 T-cell ratios $(<1)$ were observed for IciStem participants up to 7 years following allo-HSCT (Fig. 1A-B, lower panels). The increase of the CD4/CD8 ratio observed in IciS-20 between month 4 and 9 followed donor lymphocyte infusions this patient received in month 4 and 8.

Immune reconstitution after allo-HSCT occurs in two phases. The initial phase is characterized by homeostatic and antigen-driven expansion of patient's naïve and memory $\mathrm{T}$ cells that resisted conditioning regimens (before they are eliminated by graft vs host alloreactivity), and T cells from the donor that were present in the allograft or were adoptively transferred. Complete immune reconstitution is only achieved when mature naïve $\mathrm{T}$ cells from donor origin are produced by the thymus $(27,30,31)$. Therefore, we longitudinally analyzed the distribution of the different T-cell subsets after allo-HSCT to assess cellular turn-over and T-cell reconstitution in the study participants. The gating strategy used is shown in figure S3. Reconstitution of naive and memory T-cell populations showed high inter-individual differences in this group of individuals (Fig. S2 and S4). In general, early time points after HSCT were characterized by a drop in frequency of 
naïve T-cells; this held especially true for the $\mathrm{CD}^{+} \mathrm{T}$-cell compartment (Fig. 1C, left panel and S4) $(24.5 \%$ [8.1-42.3] at baseline vs. $8.2 \%$ [2.6-15.7] one month post-HSCT, median and interquartile range (IQR)). In contrast, central memory $\mathrm{CD}^{+} \mathrm{T}$-cells were more frequent early after HSCT (28.6\% [16.3-43.2] at baseline vs. 51.6\% [33.9-67.9] one-month post-HSCT, median and IQR). Overall, naïve $\mathrm{CD} 4^{+} \mathrm{T}$-cells remained low until almost 2 years post-HSCT, before some recovery could be noted (Fig. 1C left panel, and Fig. S4). This is in agreement with the strong reduction of naïve $\mathrm{T}$ cells that is initially observed after allo-HSCT in non-infected individuals. However, the recovery of naïve T cells appeared somewhat delayed with regards to what has been reported in non-HIV-infected patients in whom recovery is detected a few months after allo-HSCT (31). In the case of $\mathrm{CD}^{+} \mathrm{T}$-cells the most notable change was a progressive increase (until 6 years post-HSCT in some cases) in frequency of terminally differentiated effector $\mathrm{CD}^{+} \mathrm{T}$-cells (TemRA) after the initial drop observed post-HSCT. In contrast, CD8 ${ }^{+}$effector memory (Tem) and transitional memory (Ttm) T-cell subsets peaked at one and five months respectively and then constantly declined (Fig. 1C right panel, and Fig. S4).

In order to better understand the mechanisms of T-cell expansion, we also analyzed the expression of CD127 expression (IL-7 receptor- $\alpha$ ) on memory $\mathrm{CD}^{+}{ }^{+}$and $\mathrm{CD}^{+}$T-cells (Fig. 1D-E). The frequency of $\mathrm{CD} 127^{+}$cells was extremely low immediately post-HSCT, even among central memory (Tcm) and Ttm subsets, confirming high homeostatic expansion during this period (Fig. 1D-E, fig. S5). The frequency of $\mathrm{CD} 127^{+}$memory T-cells, in particular among $\mathrm{CD}^{+} \mathrm{T}$-cells, started to increase four months post-HSCT in most patients, which plateaued around 20 months post-HSCT (Fig. S5). This pattern likely indicates expansion of memory T cells related to new thymic generation during this phase (27), since $\mathrm{CD} 127^{+}$is highly expressed on thymic progenitors and on mature $\mathrm{T}$ cells in peripheral lymphoid tissues before they expand in response to antigens 
(32). Only one participant, IciS-01, maintained very low frequencies of CD $127^{+}$among $\mathrm{CD} 4^{+} \mathrm{Tem}$ cells and among memory $\mathrm{CD} 8^{+} \mathrm{T}$-cells (Fig. S5).

\section{High T-cell activation early after allo-HSCT: window of vulnerability for HIV reseeding}

We then studied the evolution of immune activation in $\mathrm{CD}^{+}$and $\mathrm{CD} 8^{+} \mathrm{T}$-cells following alloHSCT. Strong $\mathrm{CD}^{+}$and $\mathrm{CD} 8^{+} \mathrm{T}$-cell activation (as measured by co-expression of CD38 and HLA-DR) followed allo-HSCT and peaked between months 2 and 3 post-HSCT (Fig. 2A-B). Tcell activation decreased, and reached a plateau around 20 months post-HSCT. An exception was observed in IciS-20, who showed a strong increase of T-cell activation 9 months post allo-HSCT, following a relapse of his AML in month 8. A similar pattern was found for T-cell proliferation as measured by Ki-67 expression (Fig. 2C-D). Overall, the magnitude of immune activation of all patients' T-cells was directly correlated to $\mathrm{Ki}-67$ expression, consistent again with homeostatic/antigen driven expansion of the cells during this period (Fig. 2E). We also analyzed the expression of PD-1, which has been shown to be upregulated during reconstitution in lymphopenic environments to limit the reactivity of acutely expanding cells (33). PD-1 expression was higher in the $\mathrm{CD} 4^{+} \mathrm{T}$-cell than in the $\mathrm{CD} 8^{+} \mathrm{T}$-cell compartment, and peaked between month 2 and 4 post-HSCT for both $\mathrm{CD}^{+}$and $\mathrm{CD}^{+} \mathrm{T}$-cells, decreasing afterwards to baseline frequencies (Fig. 2F-G). Overall, this period of strong T-cell activation preceded the establishment of full donor chimerism, which was achieved in median 4.25 months post-HSCT. IciS-20 again was an exception with an increase of PD- $1^{+} \mathrm{CD}^{+} \mathrm{T}$-cells 9 months post allo-HSCT after relapsing AML. Interestingly, IciS-01 was the only patient who maintained high PD-1 expression in CD8 ${ }^{+} \mathrm{T}$-cells (Fig. 2F, lower panel), which may have impaired graft-vs-host reaction (34), and been associated with delayed T-cell chimerism and the persistence of detectable infected cells in this patient (7). 
Next, we analyzed the expression of HIV co-receptors CCR5 and CXCR4 in the CD4 ${ }^{+}$T-cell compartment. A general increase in the frequency of CCR5 expressing CD4 ${ }^{+} \mathrm{T}$-cells was observed during the first weeks following allo-HSCT and peaked 1-3 months after allo-HSCT, including among CCR5 $\Delta 32 / \Delta 32$ recipients (i.e. IciS-20, IciS-11, IciS-04), even though cell numbers were very low in the latter (Fig. 3A). This suggests that during the early homeostatic expansion period that followed allo-HSCT, immune activation occurred in both the remaining host cells and the donor cells. A strong increase in HLA-DR and CD38 expression was indeed observed in both $\mathrm{CCR}^{+}$and $\mathrm{CCR}^{-} \mathrm{CD}^{+}{ }^{+}$T-cells from IciS-20 three months after allo-HSCT (Fig. S6). As expected, CCR5 expression was lost in all of the patients who received a CCR5 $\Delta 32$ homozygous graft several months after allo-HSCT and after achieving a full T-cell chimerism (Fig. 3A, right panel). The frequency of $\mathrm{CCR} 5^{+} \mathrm{CD} 4^{+} \mathrm{T}$-cells decreased to baseline for the individuals who did not receive CCR $5 \Delta 32 / \Delta 32$ cells.

The frequency of $\mathrm{CXCR} 4^{+} \mathrm{CD} 4^{+} \mathrm{T}$-cells also increased early after allo-HSCT (Fig. 3B). In contrast, we detected a drop of $\mathrm{CD}^{+} \mathrm{T}$-cells that expressed the gut migration marker $\alpha 4 \beta 7$ integrin, which was also described to bind HIV virions (35), early after allo-HSCT (Fig. 3C-D) and only regained baseline frequencies several months after allo-HSCT.

Overall, our results show that initial weeks following allo-HSCT are characterized by the presence of few but highly activated $\mathrm{CD} 4^{+} \mathrm{T}$-cells from both donor and recipient individuals. This supposes 
a risk for HIV reservoir reseeding in the absence of complete pharmacological or genetic protection of donor cells.

\section{HIV-specific $\mathrm{CD8}^{+}$T-cell responses primed after HSCT}

Next, we evaluated how the depletion and replenishment of the T-cell compartment that accompanied allo-HSCT impacted the HIV-specific $\mathrm{CD} 8^{+} \mathrm{T}$-cell response. We monitored the frequency of $\mathrm{CD}^{+}$T-cells that were able to produce cytokines (IL-2, IFN $\gamma, \mathrm{TNF} \alpha$ ) and/or degranulate (assessed by CD107a expression) in response to stimulation with pools of overlapping peptides spanning HIV-1 Pol, Gag and Nef (Fig. 4A). As expected, HIV-specific CD8 ${ }^{+}$T-cell responses, which were readily detected at baseline, could not be detected during the initial weeks that followed allo-HSCT, in most cases due to the virtual absence of circulating $\mathrm{CD}^{+} \mathrm{T}$-cells at those early time-points (Fig. 4B). However, HIV-specific CD8 ${ }^{+}$T-cells could be detected several months after allo-HSCT, and their frequency increased coinciding with the expansion of the CD8 ${ }^{+}$ T-cell compartment (Fig. 4B), reaching a peak around month 18. In most cases, responses could be detected against several HIV-1 antigens (Fig. 4C). It is worth noting that these responses were detectable even when full donor T-cell chimerism was achieved, indicating de novo responses primed after allo-HSCT, which implies that HIV antigens were produced and presented during the expansion of donor $\mathrm{CD} 8^{+} \mathrm{T}$-cells, despite the presence of ART in these individuals. HIV-specific $\mathrm{CD}^{+} \mathrm{T}$-cell responses appear to start to wane in most IciStem participants $1.5-2$ years after alloHSCT, although significant HIV-specific $\mathrm{CD} 8^{+} \mathrm{T}$-cells still persist at low frequencies in IciS-17 and IciS-28 at 6.3 and 7.3 years after allo-HSCT, respectively. 
We then compared the quality of the HIV-specific and CMV-specific CD8 ${ }^{+} \mathrm{T}$-cells that expanded in the same individuals after allo-HSCT. Overall, the ex vivo HIV-specific $\mathrm{CD}^{+} \mathrm{T}$-cell responses exhibited limited functionality (as defined by their capacity to produce two or more simultaneous functions among degranulation, IL-2, IFN $\gamma$ or TNF $\alpha$ secretion (36)) when compared to CMVspecific $\mathrm{CD}^{+}$T-cell responses (Fig. 5A-B). This may reflect a skewed priming of HIV-specific $\mathrm{CD}^{+} \mathrm{T}$-cells as observed during natural HIV history (37). One possible difference is that in most cases IciStem participants received cells from $\mathrm{CMV}^{+}$donors (Table S2), and this has been shown to favor the rapid expansion of preexisting functional CMV-specific $\mathrm{CD} 8^{+} \mathrm{T}$-cells and enhanced control of CMV reactivation (38). In contrast, IciS-23 and IciS-28 who were CMV positive, received transplants from CMV negative donors. As depicted in Fig. 5B, highly polyfunctional CMV-specific CD8 ${ }^{+}$T-cells were found in IciS-23 at baseline, while HIV-specific CD8 ${ }^{+}$T-cells had limited functionality. Both CMV-specific and HIV-specific $\mathrm{CD} 8^{+} \mathrm{T}$-cells could not be detected one month after allo-HSCT, but responses against both HIV and CMV were detected again 2 months post-HSCT. At this time point, the frequency and functionality of both responses was limited and did not differ much. However, while CMV-specific CD8 ${ }^{+}$T-cells kept expanding and enhanced their functionality (albeit below baseline), HIV-specific CD8 ${ }^{+} \mathrm{T}$-cells did not expand and remained of limited functionality (Fig. 5B). Similar differences in the polyfunctionality of CMV- and HIV-specific cells were found for IciS-28 88 months after transplantation. Of note, during the writing of this manuscript we learned that IciS-28 spontaneously interrupted the treatment at month 110 after allo-HSCT. A retroviral syndrome began 3 months after interruption of ART, and viral rebound was detected 4 months later (Table S4), revealing the presence of replication competent virus in this individual despite viral markers were undetectable in multiple analyses performed after allo-HSCT (7). Our results therefore indicated that the limited 
289 functionality of de novo primed HIV-specific $\mathrm{CD} 8^{+} \mathrm{T}$-cells was not solely due to the conditions 290 inherent to allo-HSCT. Overall, the frequencies of HIV-specific CD8 ${ }^{+}$T-cell responses and their 291 functionality in the IciStem cohort were significantly smaller compared to other HIV-infected 292 cohorts without detectable plasma viremia, either receiving ART (cART, from the ANRS 293 TRANSBioHIV study) or controlling HIV spontaneously (HIC, from the ANRS CO21 CODEX 294 cohort)(Fig. 5C). 


\section{Discussion}

The present study provides detailed and standardized analysis of the reconstitution of the T-cell compartment and HIV-specific T-cell responses in 16 HIV-infected subjects who underwent alloHSCT. Our results indicate that immune reconstitution remains incomplete in HIV-infected individuals several years after allo-HSCT. Weakly functional de novo HIV-specific CD8 ${ }^{+} \mathrm{T}$-cell responses were primed during the initial months following allo-HSCT, suggesting the presence of HIV antigens during this period. Moreover, although allo-HSCT was accompanied by a drop of HIV infected cells in peripheral blood below detectable levels (7), we identified an initial phase of high T-cell activation after allo-HSCT which may constitute a window of risk of infection of engrafted cells in deep tissues.

Despite the great heterogeneity of the cohort in terms of underlying hematological disease, pretransplant conditioning and allo-HSCT protocol, CCR5 donor genotype and clinical course after transplantation (e.g. occurrence and severity of GvHD or opportunistic infections), some common patterns could be observed in the participants (Fig. S6). One common observation in our study is that most IciStem participants did not show restoration of the T-cell compartment to normal magnitudes despite several years of follow-up post-HSCT. Initial homeostatic expansion of the Tcell compartment involved in particular $\mathrm{CD} 8^{+} \mathrm{T}$-cell memory cells, resulting in inverted CD4/CD8 T-cell ratios. This is consistent with similar observations in non-HIV infected patients undergoing allo-HSCT $(27,28)$. However, full T-cell reconstitution requires de novo production of naïve Tcells in the thymus of the transplant recipient. T-cell reconstitution can be hampered by thymus damage during allo-HSCT due to conditioning, immunosuppression, graft-vs-host reactions, or CMV reactivation (39). In the case of HIV recipients this may be aggravated by previous HIV- 
induced thymic damage (40), which was not evaluated here. Interestingly, we observed normalization of the CD4/CD8 T-cell ratios and increased frequencies of naïve T-cells in the two patients in our study who received cells from CCR $5 \Delta 32 / \Delta 32$ donors and survived over a year. However, we cannot determine if there is a direct relationship between immune reconstitution and engraftment with CCR $5 \Delta 32 / \Delta 32$ cells.

Another clear finding was the occurrence of a generalized strong immune activation of the circulating T-cell compartment as evidenced by high HLA-DR, CD38 and PD-1 expression, and low CD127 expression in $\mathrm{CD}^{+}$and $\mathrm{CD}^{+} \mathrm{T}$-cells. This immune activation was observed before full donor chimerism was typically reached, and lasted for 6-9 months after allo-HSCT. Such an activation phase is consistent with the observations after allo-HSCT in non-HIV-infected recipients, in particular in patients who developed acute and/or chronic GvHD (41-43), and is largely related to the expansion of T-cells in response to cytokines and antigens, two forms of proliferation that have also been implicated in the persistence of the HIV- reservoir size $(44,45)$. It is worth noting that we observed an increase in the frequency of CCR $5^{+}$cells in all IciStem patients during this period, either receiving cells from CCR5WT donors or from CCR5 $\Delta 32$ donors. Enhanced CCR5 expression after allo-HSCT has been associated with increased probability of GvHD in non-HIV-infected patients undergoing allo-HSCT, which can be mitigated by maraviroc (anti-CCR5) treatment (46). It is unknown whether maraviroc containing regimens might offer additional benefits to HIV-infected patients undergoing transplantation.

During this time period, expanded T-cells are characterized by qualitative defects and impaired functionality (30), and patients undergoing allo-HSCT are prone to experience severe viral 
reactivations such as CMV or EBV $(16,29)$. In the case of HIV-infected patients, the strong activation of both donor and host $\mathrm{CD} 4^{+} \mathrm{T}$-cells may prompt the production of HIV particles from persistently infected cells. This viral production could lead to the reseeding of the reservoir in engrafted cells if or where the pressure of the ART might not be fully effective. We did not detect an increase in plasma viremia during this period in the study participants, who remained on ART before, during and after HSCT. Nevertheless, HIV RNA could still be detected at extremely low copy numbers in a fraction of the patients during the initial 6 months following allo-HSCT, becoming undetectable later. This might represent a burst in HIV production during this period by infected cells that were being rapidly depleted.

Low frequency $\mathrm{HIV}$-specific $\mathrm{CD} 8^{+} \mathrm{T}$-cell responses appeared weeks after HSCT, expanded for several months and were still detectable even when full donor T-cell chimerism was achieved, as previously shown in another case (47). This is consistent with the generation of de novo HIVspecific $\mathrm{CD}^{+} \mathrm{T}$-cells in response to HIV antigens potentially released during the initial expansion of T-cells following HSCT or at a later time by infected cells in the tissues (48) that we could not detect in our analyses. We cannot totally exclude that some of these responses correspond to crossreactive donor $\mathrm{CD} 8^{+} \mathrm{T}$-cells that may also expand after HSCT (31). However, we found responses against different HIV antigens maintained for several years. CMV responses followed similar dynamics than HIV responses in the study participants. Despite similar magnitudes, CMV T-cell responses had superior polyfunctionality than HIV-specific T-cell responses, which were predominantly monofunctional. Most of the IciStem participants studied here were $\mathrm{CMV}^{+}$before allo-HSCT and received cells from $\mathrm{CMV}^{+}$donors. This is common practice, as allo-HSCT from $\mathrm{CMV}^{+}$donors to $\mathrm{CMV}^{+}$recipients has been repeatedly reported to limit $\mathrm{CMV}$-associated disease 
in recipients (49). Interestingly, while monofunctional CMV responses are expanded after alloHSCT from $\mathrm{CMV}^{-}$donors, highly polyfunctional $\mathrm{CMV}$ responses are detected when the allograft proceeds from $\mathrm{CMV}^{+}$donors (38), which is associated with more rapid control of $\mathrm{CMV}$ reactivation in these individuals. Along these lines, clearance of $\mathrm{HBV}$ infection after transplantation in HBV antigen-positive recipients is favored when donors had immunity from natural HBV infection $(50,51)$. Suboptimal T-cell responses are developed during the initial period following allo-HSCT, and immune control of diverse viral reactivations at this time appears only achieved upon transfer of donor derived pre-existing immunity (19). Indeed, the period following allo-HSCT is not supportive for the development of efficient T-cell immunity $(38,39,52)$ due to severe lymphopenia, limited capacity to generate new effector cells, and restricted TCR repertoire. All these defects are palliated much later when/if de novo T-cell production by the thymus is satisfactorily reestablished. This unfavorable context is consistent with the poor functionality of HIV-specific $\mathrm{CD} 8^{+} \mathrm{T}$-cells that we detected in IciStem patients after allo-HSCT. Moreover, as previously mentioned, damage of lymphoid organs associated with HIV-1 infection may further hinder the development of de novo responses in IciStem patients.

It is interesting to notice that for patient IciS-23, who received cells from a CMV ${ }^{\text {neg }}$ haploidentical sibling, both $\mathrm{CMV}$-specific and HIV-specific $\mathrm{CD}^{+}$T-cell responses had similar limited functionality two months after allo-HSCT, but CMV-specific cells, contrary to HIV-specific cells, strongly increased their polyfunctionality three months later. This suggests that there are additional particular constraints in the development of HIV-specific responses in this patient. This might be due to not yet identified intrinsic defects in the priming of the HIV-specific $\mathrm{CD} 8^{+} \mathrm{T}$-cell responses when compared to CMV. It is also likely that although some HIV antigens were produced in 
IciStem patients, sufficient to prime de novo responses, exposure to HIV antigens, contrary to CMV, was very much limited by the presence of ART and the rapidly decreasing numbers of infected cells potentially producing these antigens. Indeed, the maturation of the T-cell response and the antigen-specific repertoire appears determined by repeated encounter with antigens (53, 54). Overall, such deficiency in the development of HIV-specific CD8+ T-cells may explain the inability of HIV-infected patients to control viral relapse upon treatment discontinuation if a few infected cells persist (55).

Interestingly, $\mathrm{HIV}$-specific $\mathrm{CD}^{+} \mathrm{T}$-cells were also detectable in the patients who received CCR5 $\Delta 32 / \Delta 32$ cells. We assume that these cells were primed during the time of mixed chimerism and persisted for a few years as seen in patient IciS-19 due to the long half-life of certain memory T-cell populations, before they are diluted out. Indeed, in most cases the HIV-specific responses in IciStem patients tended to wane over time, which is suggestive of lack of continuous antigenic stimulation. The frequency of HIV-specific T-cell responses observed in the IciStem cohort was low when compared to the size of the HIV-specific T-cell response detectable in other chronically HIV-infected patients. The allo-HSCT transplanted $\mathrm{HIV}^{+}$patients described in this manuscript are unique from a virologic perspective with respect to other cohorts of $\mathrm{HIV}^{+}$individuals. With the exception of IciS-01 and IciS-20 who had detectable HIV DNA at the time of the analyses, the frequency of infected cells dropped to undetectable levels after allo-HSCT in all the other participants (7). However, in a few cases HIV-specific T-cell responses were detected many years after HSCT, and it is unclear whether this may reveal persistent infection and antigen stimulation in tissues in these individuals. In particular, a relatively high frequency of HIV-specific $\mathrm{CD} 8^{+} \mathrm{T}$ cells could be detected more than 7 years post-HSCT in patient IciS-28 who, at this time point, 
had sero-reverted and had undetectable infection in our exhaustive analyses (7). However, IciS-28 has recently experienced viral rebound after spontaneously discontinuing ART. Several clinical cases of HIV-infected patients with undetectable HIV reservoir after HSCT, who received CCR5 wildtype and heterozygous grafts, have reported viral rebound upon analytical treatment interruption $(9,12,20)$. This exposes the current limits of available virologic tools to predict rebound post-treatment interruption. Further analysis of additional cases will be needed to determine whether the persistence of HIV-specific T-cells might be a sensitive indicator of the presence of HIV reservoir with potential replicative capacity. In contrast, IciS-19 who received a CCR5 $\Delta 32 / \Delta 32$ graft underwent a structured ART interruption and had not shown detectable viremia one year later $(56,57)$. In this patient, while most HIV markers were negative in blood and tissues, a few positive HIV DNA signals were detected by in situ hybridization in lymph nodes. It is therefore possible that a few infected cells are still present several years after allo-HSCT even in individuals who received CCR $5 \Delta 32 / \Delta 32$ transplants. Therefore, despite the strong diminution in the viral reservoir associated with allo-HSCT, the presence of additional effective barriers appears determinant to achieve HIV remission (13). In the case of the individuals not receiving cells from CCR $5 \Delta 32 / \Delta 32$ donors, this might require the genetic modification of the cells to induce HIV resistance or the implementation of immunotherapies to boost immune responses. In the context of allo-HSCT several strategies, such as infusion of CAR T cells or adoptive transfer of antigen-specific cells derived ex vivo from naïve T cells from negative donors are being explored to control relapse of chronic infections $(19,58,59)$. Adoptive transfer of antigen-specific cells expanded ex vivo has shown clinical efficacy against CMV, EBV and adenovirus (60) and might constitute a suitable strategy to improve $\mathrm{CD} 8^{+} \mathrm{T}$-cell immunity against HIV after allo-HSCT. In addition, infusion of broadly neutralizing antibodies at the time of treatment interruption might not 
only limit relapse of HIV infection but also favor the development of new autologous responses against HIV (61).

This study has certain limitations, most of them inherent to the observational nature of diverse clinical cases: i) patients were heterogeneous in terms of pre-transplant conditioning, transplant protocols (including the presence of immunosuppressive drugs) and CCR5 donor genotype, and also differed in the timing and extent of graft-vs-host reactions and delay to full donor chimerism; ii) PBMCs were not available for each patient at the same timepoints and discussion has been sometimes extrapolated to observed general trends; iii) due to cell number limitations, we had to focus our analyses on limited phenotypical markers and antigen-specific responses; iv) finally, we could not analyze in parallel non-HIV-infected individuals undergoing allo-HSCT, although Tcell reconstitution has been extensively studied and reported in this population, offering solid reference for comparison with our own results.

The IciStem consortium aims to find correlates for the persistence of an HIV reservoir and for the outcome after allo-HSCT. At this point, when most analyzed participants are still on ART, no conclusion can be drawn on the divergences between patients for any of the parameters described here, in particular regarding their potential to identify those individuals who could be safely taken off ART. However, this study provides a detailed outline of particularities of the T-cell compartment in this cohort post-HSCT that might be helpful to guide future interventions aiming at HIV cure in allo-HCST and other patients. Our results suggest that there is a risk of reseeding of the HIV reservoir during the first weeks that follow allo-HSCT, and that dysfunctions in the 
reconstituted T-cell compartment may limit the capacity of $\mathrm{CD} 8^{+} \mathrm{T}$-cells to contain the virus if 457 treatment is discontinued.

458 


\section{Materials and Methods}

\section{Study design}

This was an observational study nested in the IciStem collaborative (http://icistem.org), which investigates the potential for HIV cure by allogeneic stem cell transplantation. The purpose of the study was to analyze the T-cell compartment in HIV infected individuals receiving allo-HSCT for diverse hematological malignancies. Individuals enrolled in the IciStem program are included either prospectively starting at baseline preceding their allo-HSCT, or months or years after having received allo-HSCT. All samples are stored in a centralized manner. The present study describes the immune responses of the first 16 HIV positive individuals with severe hematological diseases who underwent allo- HSCT transplantation recruited within the observational IciStem cohort. These individuals were clinically monitored at eight medical centers in six countries. All participants gave written consent in this study that was approved in the local ethic boards. The samples were thawed in the respective research laboratories where analyses were performed retrospectively.

HIV-specific CD8+ T-cell responses of IciStem participants were compared to those from other individuals with HIV analyzed at the same period of time. HIV controllers(HIC) included in this study participated to the ANRS CO21 Codex cohort and were defined as individuals naïve of antiretroviral treatment and whose last 5 consecutive plasma HIV RNA values were below 400 copies/ml. HIV-infected individuals on antiretroviral treatment were included in the ANRS TRANSbio HIV study. The TRANSbioHIV study and CODEX CO21 cohort were approved by the Ethics Review Committee (Comité de protection des personnes) of Île-de-France VII. Samples were obtained and analyzed after obtaining written informed consent in accordance with the Declaration of Helsinki. 


\section{Residual viremia by ultra-sensitive viral load assay}

Residual viremia (HIV RNA) was measured by ultracentrifugation of up to $9 \mathrm{ml}$ of plasma at $170,000 \mathrm{~g}$ at $4^{\circ} \mathrm{C}$ for $30 \mathrm{~min}$, followed by viral RNA extraction using the m2000sp Abbot RealTime HIV-1 Assay device and laboratory-defined applications software from the instrument (62). HIV1 RNA copies in the low range were determined by an in-house calibration curve set (range, 10103 absolute copies) (63), which had previously been validated using a standard HIV-1 DNA control from the WHO in the range of $128-0.5$ copies per ml. Limit of detection was calculated relative to the plasma volume used in each sample (down to $0.5 \mathrm{HIV}-1 \mathrm{RNA}$ copies $/ \mathrm{mL}$ when using $9 \mathrm{~mL}$ of plasma).

\section{Cell-associated HIV DNA quantities}

HIV DNA in CD4+ T cells was repeatedly measured before and after alloHSCT in each participant, as previously described (64). Total DNA from CD4+ T-cells was isolated using DNeasy Blood \& Tissue kit (Qiagen). Ultra-sensitive HIV DNA quantification was performed using primers in the very conserved HIV-LTR region and the pol region and total cellular DNA was quantified using an RNAseP (RPP30, Ribonuclease P/MRP Subunit P30) primer and probe set. All assays were performed on the QX200 Droplet Digital PCR System (Bio-Rad).

\section{Flow cytometry phenotyping}

All analyses were performed with thawed peripheral blood mononuclear cells (PBMCs) as previously described(65). At least $1 \times 10^{6} \mathrm{PBMCs}$ were stained with a fixable viability dye (Zombie 
NIR Fixable Viability Kit, BioLegend). This was followed by incubation with unlabeled mouse anti-human $\alpha 4 \beta 7$ antibody ( obtained through the NIH AIDS Reagent Program, Division of AIDS, NIAID, NIH: Anti-Human $\alpha 4-\beta 7$ integrin Monoclonal (Act-1) (cat\#11718) from Dr. A. A. Ansari." (Act-1) (66)), a secondary staining with fluorochrome labeled rat anti-mouse antibody (BD Biosciences) and an Fc-blocking step compatible with CD16 and CD32 staining (Human TruStain FcX, BioLegend). Then, fluorochrome-conjugated antibodies (clone, company) directed against the following cell surface markers were added directly: CD3 (UCHT1, BioLegend), CD4 (SK3, BioLegend), CD8 (RPA-T8, BioLegend), CCR5 (2D7, BD Biosciences), CXCR4 (12G5, BioLegend), CD45RA (HI100, BioLegend), CCR7 (G043H7, BioLegend), CD27 (M-T271, BD), HLA-DR (L243, BioLegend), CD38 (HB-7, BioLegend), CD25 (M-A251, BioLegend), PD-1 (EH12.2H7, BioLegend), CD127 (A019D5, BioLegend), CD19 (HIB19, BioLegend), CD14 (M5E2, BioLegend). The proliferation capacity was measured via intranuclear staining of Ki-67 using a fixation and permeabilization kit optimized for staining of transcription factors and nuclear proteins (Foxp3/Transcription Factor Staining Buffer Set, eBioscience) and anti-Ki-67 antibody (Ki-67, BioLegend), according to the manufacturer's protocol. All samples were acquired on an LSR Fortessa flow cytometer (BD Biosciences). Raw data were analysed with Diva (BD Biosciences) and FlowJo software version 10.4.2 (TreeStar Inc.).

The differentiation into naïve, central memory (Tcm), early (TemRO) and late effector memory (TemRA) T-cells over time was analyzed via expression of CCR7 and CD45RA (Figure S2.)(67). TemRO cells were further subdivided into CD27 positive, transitional memory T-cells (Ttm) and CD27 negative effector memory T-cells (Tem)(68). 


\section{T-cell stimulation and intracellular cytokine staining}

Purified PBMC were thawed and rested overnight at $37^{\circ} \mathrm{C}$ in RPMI medium (RPMI 1640 supplemented with L-glutamine and antibiotics) with 20\% heat-inactivated FCS. Cells were then incubated with overlapping peptide pools encompassing HIV-1 consensus subtype B Gag, Pol, and Nef or HCMV pp65 (all obtained through the NIH AIDS Reagent Program, Division of AIDS, NIAID, NIH, cat \#12425,\#12438,\#12545 and \#11549 respectively) $(2 \mu \mathrm{g} / \mathrm{ml})$ and anti-CD28/antiCD49d co-stimulation ( $1 \mu \mathrm{L} / \mathrm{mL}$; BD Biosciences). No peptides were added in the negative controls. Phorbol myristate acetate $(80 \mathrm{ng} / \mathrm{mL})$ together with ionomycin $(1 \mu \mathrm{g} / \mathrm{mL}$; Sigma-Aldrich $)$ were used as positive control. Anti-CD107a V450 (BD Bioscience) was added to all conditions. Golgi stop (1 $\mu \mathrm{g} / \mathrm{mL}$; BD Biosciences) and Brefeldin A (10 $\mu \mathrm{g} / \mathrm{mL}$; Sigma-Aldrich) were added 30 min after the start of all incubations. PBMCs were stimulated for 6 hours. Cells were then stained with the LIVE/DEAD Fixable Aqua Dead Cell Stain kit (Thermo Fisher Scientific), and with anti-CD3-Alexa700, anti-CD4-APC and anti-CD8a APC-Cy7 antibodies (BD Bioscience). Cytofix/Cytoperm (BD Biosciences) was used for cell permeabilization prior to staining for intracellular markers. Intracellular staining used anti-IFN $\gamma$ PE-Cy7, anti-IL-2 FITC, anti-TNF $\alpha$ PE-CF594 (BD Biosciences). Cell staining was then measured with a LSRII flow cytometer (BD

Bioscience). Results were analyzed with FlowJo v10.5. Due to limited number of circulating Tcells at some time points after allo-HSCT, results were only considered when at least $1000 \mathrm{CD} 8^{+}$ T-cells could be analyzed and the number of positive events was at least $50 \%$ higher than the negative control.

\section{Statistical analysis}


549 Medians, means and interquartile ranges were calculated using Graph Pad Prism 7 software and 550 Microsoft Excel 15. Comparisons were done with non-parametric ANOVA analysis.

551

552

553

554

555 
1. G. Hutter, D. Nowak, M. Mossner, S. Ganepola, A. Mussig, K. Allers, T. Schneider, J. Hofmann, C. Kucherer, O. Blau, I. W. Blau, W. K. Hofmann, E. Thiel, Long-term control of HIV by CCR5 Delta32/Delta32 stem-cell transplantation. N Engl J Med 360, 692-698 (2009).

2. R. Liu, W. A. Paxton, S. Choe, D. Ceradini, S. R. Martin, R. Horuk, M. E. MacDonald, H. Stuhlmann, R. A. Koup, N. R. Landau, Homozygous defect in HIV-1 coreceptor accounts for resistance of some multiply-exposed individuals to HIV-1 infection. Cell 86, 367-377 (1996).

3. M. Samson, F. Libert, B. J. Doranz, J. Rucker, C. Liesnard, C. M. Farber, S. Saragosti, C. Lapoumeroulie, J. Cognaux, C. Forceille, G. Muyldermans, C. Verhofstede, G. Burtonboy, M. Georges, T. Imai, S. Rana, Y. Yi, R. J. Smyth, R. G. Collman, R. W. Doms, G. Vassart, M. Parmentier, Resistance to HIV-1 infection in caucasian individuals bearing mutant alleles of the CCR-5 chemokine receptor gene. Nature 382, $722-725$ (1996). 4. R. K. Gupta, S. Abdul-Jawad, L. E. McCoy, H. P. Mok, D. Peppa, M. Salgado, J. Martinez-Picado, M. Nijhuis, A. M. J. Wensing, H. Lee, P. Grant, E. Nastouli, J. Lambert, M. Pace, F. Salasc, C. Monit, A. Innes, L. Muir, L. Waters, J. Frater, A. M. L. Lever, S. G. Edwards, I. H. Gabriel, E. Olavarria, HIV-1 remission following CCR5Delta32/Delta32 haematopoietic stem-cell transplantation. Nature, (2019).

5. R. K. Gupta, D. Peppa, A. L. Hill, C. Galvez, M. Salgado, M. Pace, L. E. McCoy, S. A. Griffith, J. Thornhill, A. Alrubayyi, L. E. P. Huyveneers, E. Nastouli, P. Grant, S. G. Edwards, A. J. Innes, J. Frater, M. Nijhuis, A. M. J. Wensing, J. Martinez-Picado, E. Olavarria, Evidence for HIV-1 cure after CCR5Delta32/Delta32 allogeneic haemopoietic stem-cell transplantation 30 months post analytical treatment interruption: a case report. Lancet HIV, (2020).

6. A. Mikhailova, J. C. Valle-Casuso, A. Saez-Cirion, Cellular Determinants of HIV Persistence on Antiretroviral Therapy. Advances in experimental medicine and biology 1075, 213-239 (2018).

7. M. Salgado, M. Kwon, C. Galvez, J. Badiola, M. Nijhuis, A. Bandera, P. Balsalobre, P. Miralles, I. Buno, C. Martinez-Laperche, C. Vilaplana, M. Jurado, B. Clotet, A. Wensing, J. Martinez-Picado, J. L. Diez-Martin, C. IciStem, Mechanisms That Contribute to a Profound Reduction of the HIV-1 Reservoir After Allogeneic Stem Cell Transplant. Ann Intern Med 169, 674-683 (2018).

8. M. Salgado, C. Gálvez, M. Nijhuis, M. Kwon, J. Badiola, A. Bandera, B. Jensen, L. Vandekerckhove, M. Jurado, K. Raj, J. Schulze zur Wiesch, M. Nabergoj, G. Hutter, R. Saldaña-Moreno, L. Barrett, J. Kuball, A. SaezCirión, J. Luis Diez-Martin, A. Wensing, J. Martinez-Picado, f. t. IciStem-Consortium, paper presented at the Functional Cures and the Eradication of HIV, Whistler, Canada March 28, 20192019.

9. K. K. Koelsch, T. A. Rasmussen, W. J. Hey-Nguyen, C. Pearson, Y. Xu, M. Bailey, K. H. Marks, S. C. Sasson, M. S. Taylor, R. Tantau, S. Obeid, B. Milner, O. Morrissey, A. N. Pinto, K. Suzuki, M. P. Busch, S. M. Keating, P. Kaiser, S. Yukl, J. K. Wong, B. M. Hiener, S. Palmer, J. Zaunders, J. J. Post, D. J. Chan, S. Avery, S. T. Milliken, A. D. Kelleher, S. R. Lewin, D. A. Cooper, Impact of Allogeneic Hematopoietic Stem Cell Transplantation on the HIV Reservoir and Immune Response in 3 HIV-Infected Individuals. J Acquir Immune Defic Syndr 75, 328-337 (2017).

10. L. Kordelas, J. Verheyen, D. W. Beelen, P. A. Horn, A. Heinold, R. Kaiser, R. Trenschel, D. Schadendorf, U. Dittmer, S. Esser, H. I. V. A. G. Essen, Shift of HIV tropism in stem-cell transplantation with CCR5 Delta32 mutation. N Engl J Med 371, 880-882 (2014).

11. T. J. Henrich, Z. Hu, J. Z. Li, G. Sciaranghella, M. P. Busch, S. M. Keating, S. Gallien, N. H. Lin, F. F. Giguel, L. Lavoie, V. T. Ho, P. Armand, R. J. Soiffer, M. Sagar, A. S. Lacasce, D. R. Kuritzkes, Long-term reduction in peripheral blood HIV type 1 reservoirs following reduced-intensity conditioning allogeneic stem cell transplantation. J Infect Dis 207, 1694-1702 (2013).

12. N. W. Cummins, S. Rizza, M. R. Litzow, S. Hua, G. Q. Lee, K. Einkauf, T. W. Chun, F. Rhame, J. V. Baker, M. P. Busch, N. Chomont, P. G. Dean, R. Fromentin, A. T. Haase, D. Hampton, S. M. Keating, S. M. Lada, T. H. Lee, S. Natesampillai, D. D. Richman, T. W. Schacker, S. Wietgrefe, X. G. Yu, J. D. Yao, J. Zeuli, M. Lichterfeld, A. D. Badley, Extensive virologic and immunologic characterization in an HIV-infected individual following allogeneic stem cell transplant and analytic cessation of antiretroviral therapy: A case study. PLoS Med 14, e1002461 (2017).

13. A. Saez-Cirion, M. Muller-Trutwin, The Yellow Brick Road towards HIV Eradication. Trends Immunol 40, 465-467 (2019). 
14. M. Boeckh, W. Leisenring, S. R. Riddell, R. A. Bowden, M. L. Huang, D. Myerson, T. Stevens-Ayers, M. E. Flowers, T. Cunningham, L. Corey, Late cytomegalovirus disease and mortality in recipients of allogeneic hematopoietic stem cell transplants: importance of viral load and T-cell immunity. Blood 101, 407-414 (2003). 15. A. Knoll, S. Boehm, J. Hahn, E. Holler, W. Jilg, Long-term surveillance of haematopoietic stem cell recipients with resolved hepatitis B: high risk of viral reactivation even in a recipient with a vaccinated donor. $J$ Viral Hepat 14, 478-483 (2007).

16. J. W. van Esser, B. van der Holt, E. Meijer, H. G. Niesters, R. Trenschel, S. F. Thijsen, A. M. van Loon, F. Frassoni, A. Bacigalupo, U. W. Schaefer, A. D. Osterhaus, J. W. Gratama, B. Lowenberg, L. F. Verdonck, J. J. Cornelissen, Epstein-Barr virus (EBV) reactivation is a frequent event after allogeneic stem cell transplantation (SCT) and quantitatively predicts EBV-lymphoproliferative disease following T-cell--depleted SCT. Blood 98, 972978 (2001).

17. C. M. Bollard, H. E. Heslop, T cells for viral infections after allogeneic hematopoietic stem cell transplant. Blood 127, 3331-3340 (2016).

18. A. M. Leen, H. E. Heslop, M. K. Brenner, Antiviral T-cell therapy. Immunol Rev 258, 12-29 (2014).

19. P. Moss, A. Rickinson, Cellular immunotherapy for viral infection after HSC transplantation. Nat Rev Immunol 5, 9-20 (2005).

20. T. J. Henrich, E. Hanhauser, F. M. Marty, M. N. Sirignano, S. Keating, T. H. Lee, Y. P. Robles, B. T. Davis, J. Z. Li, A. Heisey, A. L. Hill, M. P. Busch, P. Armand, R. J. Soiffer, M. Altfeld, D. R. Kuritzkes, Antiretroviral-free HIV-1 remission and viral rebound after allogeneic stem cell transplantation: report of 2 cases. Ann Intern Med 161, 319-327 (2014).

21. M. Rothenberger, J. E. Wagner, A. Haase, D. Richman, B. Grzywacz, M. Strain, S. Lada, J. Estes, C. V. Fletcher, A. T. Podany, J. Anderson, T. Schmidt, S. Wietgrefe, T. Schacker, M. R. Verneris, Transplantation of CCR532 Homozygous Umbilical Cord Blood in a Child With Acute Lymphoblastic Leukemia and Perinatally Acquired HIV Infection. Open forum infectious diseases 5, ofy090 (2018).

22. C. P. Passaes, A. Saez-Cirion, HIV cure research: advances and prospects. Virology 454-455, 340-352 (2014).

23. A. Alousi, T. Wang, M. T. Hemmer, S. R. Spellman, M. Arora, D. R. Couriel, J. Pidala, P. Anderlini, M. Boyiadzis, C. N. Bredeson, J. Y. Cahn, M. S. Cairo, S. M. Gadalla, S. K. Hashmi, R. P. Gale, J. Kanda, R. T. Kamble, M. A. Kharfan-Dabaja, M. R. Litzow, O. Ringden, A. A. Saad, K. R. Schultz, L. F. Verdonck, E. K. Waller, J. A. Yared, S. G. Holtan, D. J. Weisdorf, Peripheral Blood versus Bone Marrow from Unrelated Donors: Bone Marrow Allografts Have Improved Long-Term Overall and Graft-versus-Host Disease-Free, Relapse-Free Survival. Biol Blood Marrow Transplant 25, 270-278 (2019).

24. C. Anasetti, B. R. Logan, S. J. Lee, E. K. Waller, D. J. Weisdorf, J. R. Wingard, C. S. Cutler, P. Westervelt, A. Woolfrey, S. Couban, G. Ehninger, L. Johnston, R. T. Maziarz, M. A. Pulsipher, D. L. Porter, S. Mineishi, J. M. McCarty, S. P. Khan, P. Anderlini, W. I. Bensinger, S. F. Leitman, S. D. Rowley, C. Bredeson, S. L. Carter, M. M. Horowitz, D. L. Confer, Blood, N. Marrow Transplant Clinical Trials, Peripheral-blood stem cells versus bone marrow from unrelated donors. N Engl J Med 367, 1487-1496 (2012).

25. R. F. Ambinder, J. Wu, B. Logan, C. M. Durand, R. Shields, U. R. Popat, R. F. Little, D. K. McMahon, J. Cyktor, J. W. Mellors, E. Ayala, L. D. Kaplan, A. Noy, R. J. Jones, A. Howard, S. J. Forman, D. Porter, C. ArceLara, P. Shaughnessy, L. Sproat, S. K. Hashmi, A. M. Mendizabal, M. M. Horowitz, W. H. Navarro, J. C. Alvarnas, Allogeneic Hematopoietic Cell Transplant for HIV Patients with Hematologic Malignancies: the BMT CTN0903/AMC-080 Trial. Biol Blood Marrow Transplant, (2019).

26. G. Hutter, J. A. Zaia, Allogeneic haematopoietic stem cell transplantation in patients with human immunodeficiency virus: the experiences of more than 25 years. Clin Exp Immunol 163, 284-295 (2011). 27. J. Ogonek, M. Kralj Juric, S. Ghimire, P. R. Varanasi, E. Holler, H. Greinix, E. Weissinger, Immune Reconstitution after Allogeneic Hematopoietic Stem Cell Transplantation. Front Immunol 7, 507 (2016). 28. M. R. van den Brink, E. Velardi, M. A. Perales, Immune reconstitution following stem cell transplantation. Hematology Am Soc Hematol Educ Program 2015, 215-219 (2015).

29. C. Heining, A. Spyridonidis, E. Bernhardt, J. Schulte-Monting, D. Behringer, C. Grullich, A. Jakob, H. Bertz, J. Finke, Lymphocyte reconstitution following allogeneic hematopoietic stem cell transplantation: a retrospective study including 148 patients. Bone Marrow Transplant 39, 613-622 (2007).

30. T. J. Fry, C. L. Mackall, Immune reconstitution following hematopoietic progenitor cell transplantation: challenges for the future. Bone Marrow Transplant 35 Suppl 1, S53-57 (2005).

31. W. Krenger, B. R. Blazar, G. A. Hollander, Thymic T-cell development in allogeneic stem cell transplantation. Blood 117, 6768-6776 (2011).

32. C. D. Surh, J. Sprent, Homeostasis of naive and memory T cells. Immunity 29, 848-862 (2008). 
33. S. J. Lin, C. D. Peacock, K. Bahl, R. M. Welsh, Programmed death-1 (PD-1) defines a transient and dysfunctional oligoclonal T cell population in acute homeostatic proliferation. J Exp Med 204, 2321-2333 (2007).

34. A. Saha, K. Aoyama, P. A. Taylor, B. H. Koehn, R. G. Veenstra, A. Panoskaltsis-Mortari, D. H. Munn, W. J. Murphy, M. Azuma, H. Yagita, B. T. Fife, M. H. Sayegh, N. Najafian, G. Socie, R. Ahmed, G. J. Freeman, A. H. Sharpe, B. R. Blazar, Host programmed death ligand 1 is dominant over programmed death ligand 2 expression in regulating graft-versus-host disease lethality. Blood 122, 3062-3073 (2013).

35. A. Sivro, A. Schuetz, D. Sheward, V. Joag, S. Yegorov, L. J. Liebenberg, N. Yende-Zuma, A. Stalker, R. S. Mwatelah, P. Selhorst, N. Garrett, N. Samsunder, A. Balgobin, F. Nawaz, C. Cicala, J. Arthos, A. S. Fauci, A. O. Anzala, J. Kimani, B. S. Bagaya, N. Kiwanuka, C. Williamson, R. Kaul, J. S. Passmore, N. Phanuphak, J. Ananworanich, A. Ansari, Q. Abdool Karim, S. S. Abdool Karim, L. R. McKinnon, Caprisa, R. V. s. groups, Integrin alpha4beta7 expression on peripheral blood CD4(+) T cells predicts HIV acquisition and disease progression outcomes. Sci Transl Med 10, (2018).

36. M. R. Betts, M. C. Nason, S. M. West, S. C. De Rosa, S. A. Migueles, J. Abraham, M. M. Lederman, J. M. Benito, P. A. Goepfert, M. Connors, M. Roederer, R. A. Koup, HIV nonprogressors preferentially maintain highly functional HIV-specific CD8+ T cells. Blood 107, 4781-4789 (2006).

37. V. Appay, L. Papagno, C. A. Spina, P. Hansasuta, A. King, L. Jones, G. S. Ogg, S. Little, A. J. McMichael, D. D. Richman, S. L. Rowland-Jones, Dynamics of T cell responses in HIV infection. J Immunol 168, 3660-3666 (2002).

38. W. Zhou, J. Longmate, S. F. Lacey, J. M. Palmer, G. Gallez-Hawkins, L. Thao, R. Spielberger, R. Nakamura, S. J. Forman, J. A. Zaia, D. J. Diamond, Impact of donor CMV status on viral infection and reconstitution of multifunction CMV-specific T cells in CMV-positive transplant recipients. Blood 113, 6465-6476 (2009).

39. M. S. Chaudhry, E. Velardi, F. Malard, M. R. van den Brink, Immune Reconstitution after Allogeneic Hematopoietic Stem Cell Transplantation: Time To T Up the Thymus. J Immunol 198, 40-46 (2017).

40. P. Ye, D. E. Kirschner, A. P. Kourtis, The thymus during HIV disease: role in pathogenesis and in immune recovery. Current HIV research 2, 177-183 (2004).

41. B. M. Grogan, L. Tabellini, B. Storer, T. E. Bumgarner, C. C. Astigarraga, M. E. Flowers, S. J. Lee, P. J. Martin, E. H. Warren, J. A. Hansen, Activation and expansion of CD8(+) T effector cells in patients with chronic graft-versus-host disease. Biol Blood Marrow Transplant 17, 1121-1132 (2011).

42. P. Khandelwal, V. Chaturvedi, E. Owsley, A. Lane, D. Heyenbruch, C. M. Lutzko, T. Leemhuis, M. S. Grimley, A. S. Nelson, S. M. Davies, M. B. Jordan, R. A. Marsh, CD38(bright)CD8(+) T Cells Associated with the Development of Acute GVHD Are Activated, Proliferating, and Cytotoxic Trafficking Cells. Biol Blood Marrow Transplant, (2019).

43. M. Paz Morante, J. Briones, E. Canto, H. Sabzevari, R. Martino, J. Sierra, J. L. Rodriguez-Sanchez, S. Vidal, Activation-associated phenotype of CD3 T cells in acute graft-versus-host disease. Clin Exp Immunol 145, 36-43 (2006).

44. N. Chomont, M. El-Far, P. Ancuta, L. Trautmann, F. A. Procopio, B. Yassine-Diab, G. Boucher, M. R. Boulassel, G. Ghattas, J. M. Brenchley, T. W. Schacker, B. J. Hill, D. C. Douek, J. P. Routy, E. K. Haddad, R. P. Sekaly, HIV reservoir size and persistence are driven by T cell survival and homeostatic proliferation. Nat Med 15, 893-900 (2009).

45. F. R. Simonetti, M. D. Sobolewski, E. Fyne, W. Shao, J. Spindler, J. Hattori, E. M. Anderson, S. A. Watters, S. Hill, X. Wu, D. Wells, L. Su, B. T. Luke, E. K. Halvas, G. Besson, K. J. Penrose, Z. Yang, R. W. Kwan, C. Van Waes, T. Uldrick, D. E. Citrin, J. Kovacs, M. A. Polis, C. A. Rehm, R. Gorelick, M. Piatak, B. F. Keele, M. F. Kearney, J. M. Coffin, S. H. Hughes, J. W. Mellors, F. Maldarelli, Clonally expanded CD4+ T cells can produce infectious HIV-1 in vivo. Proc Natl Acad Sci U S A 113, 1883-1888 (2016).

46. R. H. Moy, A. P. Huffman, L. P. Richman, L. Crisalli, X. K. Wang, J. A. Hoxie, R. Mick, S. G. Emerson, Y. Zhang, R. H. Vonderheide, D. L. Porter, R. Reshef, Clinical and immunologic impact of CCR5 blockade in graftversus-host disease prophylaxis. Blood 129, 906-916 (2017).

47. A. E. Woolfrey, U. Malhotra, R. D. Harrington, J. McNevin, T. J. Manley, S. R. Riddell, R. W. Coombs, F. R. Appelbaum, L. Corey, R. Storb, Generation of HIV-1-specific CD8+ cell responses following allogeneic hematopoietic cell transplantation. Blood 112, 3484-3487 (2008).

48. L. Colonna, C. W. Peterson, J. B. Schell, J. M. Carlson, V. Tkachev, M. Brown, A. Yu, S. Reddy, W. M. Obenza, V. Nelson, P. S. Polacino, H. Mack, S. L. Hu, K. Zeleski, M. Hoffman, J. Olvera, S. N. Furlan, H. Zheng, A. Taraseviciute, D. J. Hunt, K. Betz, J. F. Lane, K. Vogel, C. E. Hotchkiss, C. Moats, A. Baldessari, R. D. Murnane, C. English, C. A. Astley, S. Wangari, B. Agricola, J. Ahrens, N. Iwayama, A. May, L. Stensland, M. W. 
Huang, K. R. Jerome, H. P. Kiem, L. S. Kean, Evidence for persistence of the SHIV reservoir early after MHC haploidentical hematopoietic stem cell transplantation. Nat Commun 9, 4438 (2018).

49. J. P. Grob, J. E. Grundy, H. G. Prentice, P. D. Griffiths, A. V. Hoffbrand, M. D. Hughes, T. Tate, J. Z. Wimperis, M. K. Brenner, Immune donors can protect marrow-transplant recipients from severe cytomegalovirus infections. Lancet 1, 774-776 (1987).

50. G. K. Lau, R. Liang, C. K. Lee, S. T. Yuen, J. Hou, W. L. Lim, R. Williams, Clearance of persistent hepatitis B virus infection in Chinese bone marrow transplant recipients whose donors were anti-hepatitis B coreand anti-hepatitis B surface antibody-positive. J Infect Dis 178, 1585-1591 (1998).

51. R. Liang, How I treat and monitor viral hepatitis B infection in patients receiving intensive immunosuppressive therapies or undergoing hematopoietic stem cell transplantation. Blood 113, 3147-3153 (2009). 52. P. Reusser, S. R. Riddell, J. D. Meyers, P. D. Greenberg, Cytotoxic T-lymphocyte response to cytomegalovirus after human allogeneic bone marrow transplantation: pattern of recovery and correlation with cytomegalovirus infection and disease. Blood 78, 1373-1380 (1991).

53. D. Koning, A. I. Costa, I. Hoof, J. J. Miles, N. M. Nanlohy, K. Ladell, K. K. Matthews, V. Venturi, I. M. Schellens, J. A. Borghans, C. Kesmir, D. A. Price, D. van Baarle, CD8+ TCR repertoire formation is guided primarily by the peptide component of the antigenic complex. J Immunol 190, 931-939 (2013).

54. M. R. von Essen, M. Kongsbak, C. Geisler, Mechanisms behind functional avidity maturation in T cells. Clin Dev Immunol 2012, 163453 (2012).

55. A. L. Hill, D. I. Rosenbloom, E. Goldstein, E. Hanhauser, D. R. Kuritzkes, R. F. Siliciano, T. J. Henrich, Real-Time Predictions of Reservoir Size and Rebound Time during Antiretroviral Therapy Interruption Trials for HIV. PLoS Pathog 12, e1005535 (2016).

56. B.-E. O. Jensen, E. Knops, N. Lübke, A. Wensing, J. Martinez-Picado, M. Kaiser, M. Nijhuis, M. Salgado, T. Harrer, E. Heger, J. M. Eberhard, I. Hauber, C. Münk, D. Häussinger, G. Kobbe, in CROI (Seattle, USA, 2019). 57. B. Jensen, D. Haussinger, E. Knops, A. Wensing, J. Martinez-Picado, M. Nijhuis, M. Salgado, J. Estes, N. Lubke, in CROI. (Boston, MA, 2020).

58. P. Kongtim, D. A. Lee, L. J. Cooper, P. Kebriaei, R. E. Champlin, S. O. Ciurea, Haploidentical Hematopoietic Stem Cell Transplantation as a Platform for Post-Transplantation Cellular Therapy. Biol Blood Marrow Transplant 21, 1714-1720 (2015).

59. P. J. Hanley, J. J. Melenhorst, S. Nikiforow, P. Scheinberg, J. W. Blaney, G. Demmler-Harrison, C. R. Cruz, S. Lam, R. A. Krance, K. S. Leung, C. A. Martinez, H. Liu, D. C. Douek, H. E. Heslop, C. M. Rooney, E. J. Shpall, A. J. Barrett, J. R. Rodgers, C. M. Bollard, CMV-specific T cells generated from naive T cells recognize atypical epitopes and may be protective in vivo. Sci Transl Med 7, $285 \mathrm{ra} 263$ (2015).

$60 . \quad$ T. Kaeuferle, R. Krauss, F. Blaeschke, S. Willier, T. Feuchtinger, Strategies of adoptive T -cell transfer to treat refractory viral infections post allogeneic stem cell transplantation. J Hematol Oncol 12, 13 (2019).

61. M. Caskey, F. Klein, M. C. Nussenzweig, Broadly neutralizing anti-HIV-1 monoclonal antibodies in the clinic. Nat Med 25, 547-553 (2019).

62. S. Moron-Lopez, J. Navarro, M. Jimenez, S. Rutsaert, V. Urrea, M. C. Puertas, A. Torrella, L. De Clercq, B. P. Ribas, C. Galvez, M. Salgado, L. Vandekerckhove, J. Blanco, M. Crespo, J. Martinez-Picado, Switching From a Protease Inhibitor-based Regimen to a Dolutegravir-based Regimen: A Randomized Clinical Trial to Determine the Effect on Peripheral Blood and Ileum Biopsies From Antiretroviral Therapy-suppressed Human Immunodeficiency Virus-infected Individuals. Clin Infect Dis 69, 1320-1328 (2019).

63. A. Amendola, M. Bloisi, P. Marsella, R. Sabatini, A. Bibbo, C. Angeletti, M. R. Capobianchi, Standardization and performance evaluation of "modified" and "ultrasensitive" versions of the Abbott RealTime HIV-1 assay, adapted to quantify minimal residual viremia. J Clin Virol 52, 17-22 (2011).

64. K. J. Bosman, A. M. Wensing, A. E. Pijning, W. J. van Snippenberg, P. M. van Ham, D. M. de Jong, A. I. Hoepelman, M. Nijhuis, Development of sensitive ddPCR assays to reliably quantify the proviral DNA reservoir in all common circulating HIV subtypes and recombinant forms. J Int AIDS Soc 21, e25185 (2018).

65. J. M. Eberhard, F. Ahmad, H. S. Hong, N. Bhatnagar, P. Keudel, J. Schulze Zur Wiesch, R. E. Schmidt, D. Meyer-Olson, Partial recovery of senescence and differentiation disturbances in CD8(+) T cell effector-memory cells in HIV-1 infection after initiation of anti-retroviral treatment. Clin Exp Immunol 186, 227-238 (2016). 66. A. I. Lazarovits, R. A. Moscicki, J. T. Kurnick, D. Camerini, A. K. Bhan, L. G. Baird, M. Erikson, R. B. Colvin, Lymphocyte activation antigens. I. A monoclonal antibody, anti-Act I, defines a new late lymphocyte activation antigen. J Immunol 133, 1857-1862 (1984).

67. F. Sallusto, J. Geginat, A. Lanzavecchia, Central memory and effector memory T cell subsets: function, generation, and maintenance. Annu Rev Immunol 22, 745-763 (2004). 
68. G. Breton, N. Chomont, H. Takata, R. Fromentin, J. Ahlers, A. Filali-Mouhim, C. Riou, M. R. Boulassel, J. P. Routy, B. Yassine-Diab, R. P. Sekaly, Programmed death-1 is a marker for abnormal distribution of naive/memory T cell subsets in HIV-1 infection. J Immunol 191, 2194-2204 (2013).

\section{Supplementary materials:}

Fig. S1: Participant sampling

Fig S2: Longitudinal characterization of naïve and memory CD4+ and CD8+ T-cell populations for 3 IciStem participants included in this study

Fig. S3: Gating strategy of naïve and memory T-cell populations

Fig. S4: Reconstitution of naïve and memory T-cell populations

Fig. S5: CD127 expression on memory T-cells

Fig. S6: Frequencies of activated CCR5+ and CCR5-CD4+ T-cells during mixed chimerism

Data file S1. Primary data

Fig. S7: Sequence of hematological events and T-cell reconstitution pre and post allo-HSCT in an HIV infected cohort.

Table S1: Virologic characteristics of 16 IciStem participants included in this study

Table S2: HLA-types of 16 IciStem participants included in this study

Table S3: Longitudinal CD4+ T-cell counts of 16 IciStem participants included in this study

Table S4: Summary of main clinical events observed for IciS-28 


\section{Acknowledgments:}

We thank all individuals who participated in this study and all IciStem members for constant support and discussion of results. The authors also thank the participants and investigators of the ANRS CODEX cohort and ANRS TRANSbioHIV study. This study was funded by the amfAR (The Foundation for AIDS Research), through the amfAR Research Consortium on HIV Eradication (ARCHE) program (grants 108930-56-RGRL, 109293-59-RGRL, and 109552-61RGRL). J.M.E. and J.S.z.W. were supported by the German Center for Infection Research (DZIF) and the European HIV Alliance (EHVA). J.S.z.W. got additional funding by the German Research Agency DFG SFB1328 A12.

\section{Author contributions:}

J.M.E., J.S.z.W, J.M.P. and A.S.C. designed the study, J.M.E., M.A., C.P. and V.M. performed experiments, analyzed and interpreted the data. J.M.E., J.S.z.W. and A.S.C. interpreted the data and drafted the manuscript. B.J., E.K., L.V., J.B., A.B., K.R., J.H.E.K., P.B., M.K., J.L.D.M. provided patient samples and clinical information and assisted in their interpretation. M.C. and N.K. helped in the interpretation and revision of HSCT related data. M.S., J.M.P. and J.L.D.M. critically revised the manuscript for important intellectual content. M.N., A.W., J.M.P and A.S.C. obtained funding. M.S., J.v.L., G.H., P.B., M.K, J.L.D.M., M.N., A.W., J.M.P. and A.S.C were initiating partners of the IciStem consortium and provided constant support during the discussion and assembly of the data.

\section{Competing interests:}


B.J. reports speaker honoraria and consultancy fees from ViiV Healthcare, Gilead, Janssen, Merck

817

818

819

820

821 and Bristol-Myers Squibb outside the submitted work. L.V. reports that his institution received grants and consultancy fees from ViiV Healthcare, Gilead, Janssen and Merck outside the submitted work. A.W. reports grants and consultancy fees from ViiV Healthcare, Gilead, Janssen, Merck, CLJI, and Virology Education outside the submitted work. J.M.P. reports institutional grant and educational/consultancy fees outside the submitted work from Astra-Zeneca, Gilead Sciences, Grifols, Janssen, Merck and ViiV Healthcare. J.S.z.W. reports speaker honoraria from Gilead and MSD outside the submitted work. A.S.C. reports institutional grants and educational/consultancy fees outside the submitted work from MSD, Gilead, ViiV Healthcare, Janssen and BMS. J.v.L. is a full time employee of ViiV Healthcare and holds shares from GSK.

Data and Materials availability: All data associated with this study are present in the paper or Supplemental Materials. 
Table 1: Clinical and hematologic characteristics of 16 IciStem participants included in this study

\begin{tabular}{|c|c|c|c|c|c|c|c|c|c|c|c|c|}
\hline Patient Site & ender & $\begin{array}{c}\text { Age } \\
\quad \text { at } \\
\text { HSCT }\end{array}$ & $\begin{array}{c}\text { Hematological } \\
\text { malignancy }\end{array}$ & Graft & $\begin{array}{l}\text { CCR5 } \\
\text { status } \\
\text { donor }\end{array}$ & $\begin{array}{c}\text { HSCT } \\
\text { conditioning } \\
\text { regimen }\end{array}$ & $\begin{array}{c}\text { GvHD } \\
\text { prophylaxis }\end{array}$ & GvHD & $\begin{array}{c}\text { Complete } \\
\text { Chimerism } \\
\text { [month] }\end{array}$ & $\begin{array}{c}\text { HSCT } \\
\text { associated } \\
\text { infections }\end{array}$ & $\begin{array}{l}\text { Engraftment } \\
\text { [month] }\end{array}$ & $\begin{array}{c}\text { Outcome } \\
\text { [months } \\
\text { tost- } \\
\text { HSCT] } \\
\text { (cause of } \\
\text { death) } \\
\end{array}$ \\
\hline IciS-01 ES & M & 34 & Burkitt lymphoma & $\begin{array}{l}\text { Haploidentical } \\
\text { and cord } \\
\text { blood } \\
\text { transplant }\end{array}$ & wt/wt & $\begin{array}{c}\text { MAC: ATG, } \\
\text { FLU, BU, } \\
\text { CY }\end{array}$ & $\begin{array}{l}\text { CsA and } \\
\text { corticosteroids }\end{array}$ & no & $\begin{array}{l}\text { PB: } 2 \\
\text { T cells: } 18 \\
\text { BM: } 12\end{array}$ & BK virus & $\leq 1$ & alive [87] \\
\hline IciS-02 ES & M & 33 & $\begin{array}{c}\text { Lymphohistiocytosis } \\
\text { maligna }\end{array}$ & $\begin{array}{l}\text { s HLA-matched } \\
\text { sibling }\end{array}$ & $\mathrm{wt} / \mathrm{wt}$ & $\begin{array}{l}\text { RIC: ATG, } \\
\text { FLU, } \\
\text { melphalan }\end{array}$ & $\begin{array}{l}\text { CsA and } \\
\text { MTX }\end{array}$ & $\begin{array}{c}\text { yes } \\
\text { (severe) }\end{array}$ & $\begin{array}{l}\text { PB: } 1 \\
\text { BM: } 3.5\end{array}$ & & $<1$ & $\begin{array}{l}\text { deceased } \\
{[26]} \\
\text { (infection, } \\
\text { GVHD) }\end{array}$ \\
\hline IciS-03 ES & M & 51 & $\begin{array}{l}\text { NK-Non-Hodgkin } \\
\text { lymphoma }\end{array}$ & $\begin{array}{l}\text { HLA-identical } \\
\text { sibling }\end{array}$ & $\mathrm{wt} / \mathrm{wt}$ & $\begin{array}{l}\text { RIC: FLU, } \\
\text { melphalan }\end{array}$ & $\begin{array}{l}\text { CsA and } \\
\text { MTX }\end{array}$ & $\begin{array}{c}\text { yes } \\
\text { (mild) }\end{array}$ & $\begin{array}{l}\text { PB: } 1 \\
\text { T cells: } 1 \\
\text { BM: } 6.5\end{array}$ & no & $<1$ & alive [75] \\
\hline IciS-04 ES & M & 37 & $\begin{array}{c}\text { Diffuse large B-cell } \\
\text { lymphoma }\end{array}$ & $\begin{array}{l}\text { Haploidentical } \\
\text { and cord } \\
\text { blood } \\
\text { transplant }\end{array}$ & $\Delta 32 / \Delta 32$ & $\begin{array}{l}\text { ATG, FLU, } \\
\text { BU, CY }\end{array}$ & $\begin{array}{l}\text { CsA and short } \\
\text { course } \\
\text { corticosteroids }\end{array}$ & no & $\begin{array}{l}\text { PB?: } 73 \\
\text { days (T1) }\end{array}$ & $\begin{array}{l}\text { CMV } \\
\text { reactivation } \\
\text { (resolved } \\
\text { soon post- } \\
\text { HSCT) }\end{array}$ & $<1$ & $\begin{array}{l}\text { deceased } \\
{[2]} \\
\text { (relapse) }\end{array}$ \\
\hline IciS-05 NL & M & 52 & $\begin{array}{l}\text { Myelodysplastic } \\
\text { syndrome }\end{array}$ & $\begin{array}{l}\text { Haploidentical } \\
\text { and cord } \\
\text { blood } \\
\text { transplant }\end{array}$ & $\Delta 32 / \Delta 321$ & not disclosed & $\begin{array}{c}\text { CsA, MMF } \\
\text { and } \\
\text { corticosteroids }\end{array}$ & $\begin{array}{c}\text { yes } \\
\text { (acute) }\end{array}$ & not reached & $\begin{array}{l}\text { not } \\
\text { disclosed }\end{array}$ & not reached & $\begin{array}{l}\text { deceased } \\
{[14]} \\
\text { (relapse, } \\
\text { pneumonia) }\end{array}$ \\
\hline IciS-06 ES & M & 40 & $\begin{array}{c}\text { Relapsing Hodgkin } \\
\text { lymphoma }\end{array}$ & $\begin{array}{l}\text { HLA- } \\
\text { haploidentical } \\
\text { sibling }\end{array}$ & wt/wt & $\begin{array}{l}\text { RIC: FLU, } \\
\text { BU, CY }\end{array}$ & $\begin{array}{l}\text { CY, CsA, } \\
\text { MMF }\end{array}$ & $\begin{array}{c}\text { yes } \\
\text { (severe) }\end{array}$ & $\begin{array}{l}\text { PB: } 3 \\
\text { T cells: } 3 \\
\text { BM: } 6\end{array}$ & $\begin{array}{l}\text { CMV } \\
\text { reactivation }\end{array}$ & $<1$ & alive [57] \\
\hline IciS-08 ES & M & 57 & Myelofibrosis & $\begin{array}{l}\text { HLA- } \\
\text { haploidentical } \\
\text { sibling }\end{array}$ & wt/wt & $\begin{array}{l}\text { RIC: FLU, } \\
\text { BU, CY }\end{array}$ & $\begin{array}{l}\text { MMF, CsA, } \\
\quad \text { CY }\end{array}$ & no & n.a. & $\begin{array}{l}\text { Fungal } \\
\text { infection }\end{array}$ & not reached & $\begin{array}{l}\text { deceased } \\
\text { [2] } \\
\text { (infection) }\end{array}$ \\
\hline IciS-11 NL & M & 60 & $\begin{array}{l}\text { Acute myeloid } \\
\text { leukemia }\end{array}$ & $\begin{array}{l}\text { HLA-matched } \\
\text { unrelated } \\
\text { donor }\end{array}$ & $\Delta 32 / \Delta 32$ & not disclosed & $\begin{array}{l}\text { MMF, CsA } \\
\text { (T1 and 2) }\end{array}$ & no & not reached & $\mathrm{d}_{\text {disclosed }}^{\text {not }}$ & not reached & $\begin{array}{l}\text { deceased } \\
{[3]} \\
\text { (respiratory } \\
\text { insufficient) }\end{array}$ \\
\hline IciS-12 ES & M & 31 & $\begin{array}{l}\text { Relapsing } \\
\text { lymphoma }\end{array}$ & $\begin{array}{l}\text { Haploidentical } \\
\text { mother }\end{array}$ & $\mathrm{wt} / \mathrm{wt}$ & $\begin{array}{l}\text { RIC: FLU, } \\
\text { BU }\end{array}$ & $\begin{array}{c}\text { MMF, } \\
\text { CsA,CY }\end{array}$ & yes & $\begin{array}{l}\text { PB: } 0.5 \\
\text { T cells: } 1\end{array}$ & unknown & $<1$ & $\begin{array}{l}\text { deceased } \\
{[2]}\end{array}$ \\
\hline
\end{tabular}




\begin{tabular}{|c|c|c|c|c|c|c|c|c|c|c|c|}
\hline & & & & & & & & BM: 1 & & & (relapse) \\
\hline IciS-17 IT & $\mathrm{M}$ & 46 & $\begin{array}{c}\text { Diffuse large B cell } \\
\text { lymphoma }\end{array}$ & $\begin{array}{l}\text { HLA- } \\
\text { haploidentical wt/wt } \\
\text { sibling }\end{array}$ & $\begin{array}{l}\text { RIC: FLU, } \\
\text { Thiotepa, } \\
\text { CY }\end{array}$ & CsA, MTX & no & PB: 1 & $\begin{array}{l}\text { EBV } \\
\text { reactivation }\end{array}$ & $<1$ & alive [107] \\
\hline IciS-19 DE & $\mathrm{M}$ & 43 & $\begin{array}{l}\text { Acute myeloid } \\
\text { leukemia }\end{array}$ & $\begin{array}{l}\text { HLA-matched } \\
\text { unrelated } \Delta 32 / \Delta 32 \\
\text { donor }\end{array}$ & $\begin{array}{l}\text { RIC: FLU, } \\
\text { treosulfan }\end{array}$ & $\begin{array}{l}\text { TAC and } \\
\text { corticosteroids }\end{array}$ & $\begin{array}{c}\text { yes } \\
\text { (severe) }\end{array}$ & $\begin{array}{l}\text { PB: } 23 \\
\text { BM: } 7\end{array}$ & $\begin{array}{l}\text { HSV- } \\
\text { reactivation, } \\
\text { HHV8- } \\
\text { reactivation }\end{array}$ & $<1$ & alive [79] \\
\hline IciS-20 GB & $\mathrm{M}$ & & $\begin{array}{l}\text { Acute myeloid } \\
\text { leukemia from } \\
\text { CMML }\end{array}$ & $\begin{array}{l}\text { HLA-matched } \\
\text { unrelated } \Delta 32 / \Delta 32 \\
\text { donor }\end{array}$ & $\begin{array}{l}\text { FLU, BU, } \\
\text { campath }\end{array}$ & CsA & no & T cells: 10 & $\begin{array}{l}\text { CMV } \\
\text { reactivation; } \\
\text { EBV } \\
\text { reactivation }\end{array}$ & $<1$ & alive [42] \\
\hline IciS-23 BE & M & 59 & $\begin{array}{l}\text { Acute myeloid } \\
\text { leukemia }\end{array}$ & $\begin{array}{l}\text { Haploidentical } \\
\text { sibling }\end{array}$ & $\begin{array}{c}\text { BU, } \\
\text { cytarabine, } \\
\text { idarubicin }\end{array}$ & $\begin{array}{l}\text { MMF and } \\
\text { TAC }\end{array}$ & no & $\begin{array}{l}\text { PB: } 6 \\
\text { T cells: } 6 \\
\text { BM: } 6\end{array}$ & $\begin{array}{l}\text { Neutropenic } \\
\text { fever; CMV } \\
\text { reactivation }\end{array}$ & $<1$ & alive [35] \\
\hline IciS-27 ES & $\mathrm{m}$ & 47 & $\begin{array}{l}\text { Non-Hodgkin } \\
\text { lymphoma }\end{array}$ & $\begin{array}{l}\text { HLA-matched } \\
\text { related donor } \mathrm{wt} / \mathrm{wt}\end{array}$ & $\begin{array}{l}\text { RIC: FLU, } \\
\text { CY }\end{array}$ & $\begin{array}{l}\text { CsA and } \\
\text { MTX }\end{array}$ & $\begin{array}{l}\text { yes } \\
\text { (mild) }\end{array}$ & $\begin{array}{l}\text { T cells: } 5.5 \\
\text { month }\end{array}$ & no & $<1$ & alive [77] \\
\hline IciS-28 ES & $\mathrm{m}$ & 44 & Hodgkin lymphoma & $\begin{array}{l}\text { HLA-matched } \\
\text { unrelated wt/wt } \\
\text { donor }\end{array}$ & $\begin{array}{l}\text { RIC: FLU, } \\
\text { melphalan }\end{array}$ & $\begin{array}{l}\text { TAC and } \\
\text { Sirolimus }\end{array}$ & $\begin{array}{c}\text { yes } \\
\text { (acute) }\end{array}$ & $\begin{array}{l}\text { T cells: } 1 \\
\text { month }\end{array}$ & $\begin{array}{l}\text { CMV } \\
\text { reactivation }\end{array}$ & $<1$ & alive [120] \\
\hline IciS-29 ES & $\mathrm{m}$ & 44 & Acute leukemia & $\begin{array}{l}\text { HLA-matched } \\
\text { unrelated wt/wt } \\
\text { donor }\end{array}$ & FLU, BU & $\begin{array}{l}\text { MMF, CsA, } \\
\text { CY }\end{array}$ & $\begin{array}{c}\text { yes } \\
\text { (acute) }\end{array}$ & $\begin{array}{l}\text { PB: } 1 \\
\text { BM: } 1\end{array}$ & no & $<1$ & $\begin{array}{l}\text { deceased } \\
{[6]} \\
\text { (relapse) }\end{array}$ \\
\hline
\end{tabular}

$\mathrm{ATG}=$ antithymocyte globulin; $\mathrm{BE}=$ Belgium; $\mathrm{BU}=$ busulfan; $\mathrm{CsA}=$ cyclosporine $\mathrm{A} ; \mathrm{CY}=$ cyclophosphamide; $\mathrm{DE}=\mathrm{Germany} ; \mathrm{EBV}=\mathrm{Epstein}-\mathrm{Barr}$ virus; $\mathrm{ES}=$ Spain; FLU= fludarabine; GB= England; GvHD = graft-versus-host disease ; HHV8= human herpesvirus 8; HSV= herpes simplex virus; IT= Italy; MAC = myeloablative conditioning; $\mathrm{MMF}=$ mycophenolate mofetil; $\mathrm{MTX}=$ metho-trexate; $\mathrm{NK}=$ Natural killer cell; $\mathrm{NL}=\mathrm{Netherlands}$; RIC $=$ reduced-intensity conditioning; TAC $=$ Tacrolimus 


\section{FIGURE LEGENDS}

Figure 1: Reconstitution of the T-cell compartment in an HIV-positive cohort after alloHSCT. (A) Frequency of $\mathrm{CD}^{+}$and $\mathrm{CD}^{+} \mathrm{T}$-cells as $\%$ of $\mathrm{CD}^{+} \mathrm{T}$-cells and $\mathrm{CD} 4^{+} / \mathrm{CD} 8^{+} \mathrm{T}$-cell ratio. Symbols and lines represent one patient over time. Grey lines indicate median and $25 \%$ and $75 \%$ percentiles of T-cell frequencies in a cohort of healthy controls $(n=30)$. Open symbols represent time points where T-cell numbers were very low ( $<100 \mathrm{~T}$-cells per analysis). (B) Median frequencies of $\mathrm{CD}^{+}$and $\mathrm{CD} 8^{+} \mathrm{T}$-cell frequencies (upper panel) and median $\mathrm{CD} 4^{+} / \mathrm{CD} 8^{+}$ratios (lower panel). (C) Proportions of naive $\left(\mathrm{CCR}^{+} \mathrm{CD} 45 \mathrm{RA} A^{+}\right)$, central memory (Tcm, $\mathrm{CCR} 7^{+} \mathrm{CD} 45 \mathrm{RA}^{-}$), transitional memory (Ttm, CCR7-CD45RA-CD27 ${ }^{+}$), early effector memory (Tem, CCR7 ${ }^{-} \mathrm{CD}^{2} 5 \mathrm{RA}^{-} \mathrm{CD} 27^{-}$), and late effector memory (TemRA, CCR7-CD45RA ${ }^{+}$) populations of 16 patients total. Mean values from 2-10 patients per time point were summarized. (D) Frequencies of $\mathrm{CD} 27^{+} \mathrm{CD}^{+}$(upper panel) and $\mathrm{CD}^{+}$T-cells (lower panel). (E) Median frequencies of $\mathrm{CD} 127^{+} \mathrm{CD} 4^{+}$and $\mathrm{CD}^{+} \mathrm{T}$ cells.

Figure 2: $\mathrm{CD4}^{+}$and $\mathrm{CD8}^{+} \mathrm{T}$-cell activation is high in the early months post allo-HSCT. (A) Frequency of activated $\left(\mathrm{CD} 38^{+} \mathrm{HLA}_{-}-\mathrm{DR}^{+}\right) \mathrm{CD}^{+}$and $\mathrm{CD} 8^{+} \mathrm{T}$-cells, measured as $\%$ of $\mathrm{CD} 4^{+}$or $\mathrm{CD}^{+} \mathrm{T}$-cells, respectively. Symbols and lines represent one patient over time (B). Median frequencies of $\mathrm{CD} 38^{+} \mathrm{HLA}-\mathrm{DR}^{+} \mathrm{CD}^{+}$and $\mathrm{CD}^{+} \mathrm{T}$-cells. Medians from 2-10 patients per time point were summarized. (C) Frequency of proliferating $\left(\mathrm{Ki}-67^{+}\right) \mathrm{CD}^{+}$and $\mathrm{CD} 8^{+} \mathrm{T}$-cells. (D) Median frequencies of $\mathrm{Ki}-67^{+} \mathrm{CD} 4^{+}$and $\mathrm{CD}^{+} \mathrm{T}$-cells. (E) Correlation analysis between Ki-67 expression and HLA-DR/ CD38 co-expression of CD4 ${ }^{+}$T-cells and CD8 ${ }^{+}$T-cells. (F) Frequency of PD- $1^{+} \mathrm{CD} 4^{+}$(upper panel) and $\mathrm{CD} 8^{+} \mathrm{T}$-cells (lower panel) Symbols and lines represent one patient over time. (G) Median frequencies of PD- $1^{+} \mathrm{CD} 4^{+}$and $\mathrm{CD} 8^{+} \mathrm{T}$-cells. 
Figure 3: HIV co-receptor expression on $\mathrm{CD}^{+}$T-cells and gut migration marker $\alpha 4 \beta 7$ integrin on $\mathrm{CD}^{+}$and $\mathrm{CD8}^{+}$T-cells. (A) Frequency of CCR $5^{+} \mathrm{CD} 4+\mathrm{T}$-cells in CCR5 wt/wt and CCR $5 \Delta 32 / \mathrm{wt}$ (left panel) and CCR $5 \Delta 32 / \Delta 32$ (right panel) transplanted patients. (B) Frequency of $\mathrm{CXCR}^{+} \mathrm{CD}^{+}{ }^{+} \mathrm{T}$-cells in CCR5 wt/wt and CCR5 $\Delta 32 / \mathrm{wt}$ (left panel) and CCR5 $\Delta 32 / \Delta 32$ (right panel) transplanted patients. (C) Frequencies of $\alpha 4 \beta 7^{+} \mathrm{CD} 4^{+}$(upper panel) and $\mathrm{CD} 8^{+} \mathrm{T}$-cells (lower panel). (D) Median frequencies of $\alpha 4 \beta 7^{+} \mathrm{CD} 4^{+}$and $\mathrm{CD} 8^{+} \mathrm{T}$-cells.

Figure 4: HIV-specific immune responses are weak but recur after HSCT. (A) Representative flow cytometry plots of CD107a, IL-2, IFN $\gamma$ and TNF $\alpha$ staining after HIV-specific stimulation. (B) Frequency of HIV-specific $\mathrm{CD} 8^{+} \mathrm{T}$ cells at different times after allo-HSCT. Symbols and lines represent evolution of values over time for each patient. Open symbols (between M1-M3 after HSCT) represent time points where $\mathrm{CD}^{+} \mathrm{T}$-cell numbers were $<100$ cells per analysis. (C) Frequencies of $\mathrm{CD}^{+} \mathrm{T}$ cells exerting at least one function against HIV-1 Pol (green), Nef (red) and Gag (blue) derived peptide pools.

Figure 5: HIV-specific $\mathrm{CD8}^{+}$T-cell responses are less polyfunctional compared to $\mathrm{CMV}$ specific CD8+ T-cell responses. (A) Proportion of $\mathrm{CD}^{+} \mathrm{T}$-cells exerting simultaneous functions (blue $=1$ function, red= 2 functions, green $=3$ functions, purple $=4$ functions, among IL2, IFN $\gamma$, TNF $\alpha$ and CD107) in response to stimulation with HIV-1 or CMV peptides. The labels in the donut plots indicate the total frequency of the response. (B) Polyfunctionality of HIV- and CMVspecific $\mathrm{CD}^{+} \mathrm{T}$-cells in Icis23 patient before (baseline) and at different months after allo-HSCT. (C) Frequency of total (left panel) and polyfunctional (exerting at least three functions, center 
panel) HIV-specific $\mathrm{CD} 8^{+} \mathrm{T}$-cells (Gag+Pol responses) in Icistem patients ( $\mathrm{n}=12$, only samples beyond M3 post allo-HSCT were considered), regular HIV-infected individuals with undetectable viral loads on cART $(n=7)$ and natural HIV controllers (HIC, $n=21)$. The proportion of polyfunctional cells among the overall response is shown in the right panel. Symbols represent individual values at last time of follow up. Box plots represent 25\%-75\% quartile range. Median, maximum and minimum values are indicated. Comparisons were done with non-parametric ANOVA analysis. 
A
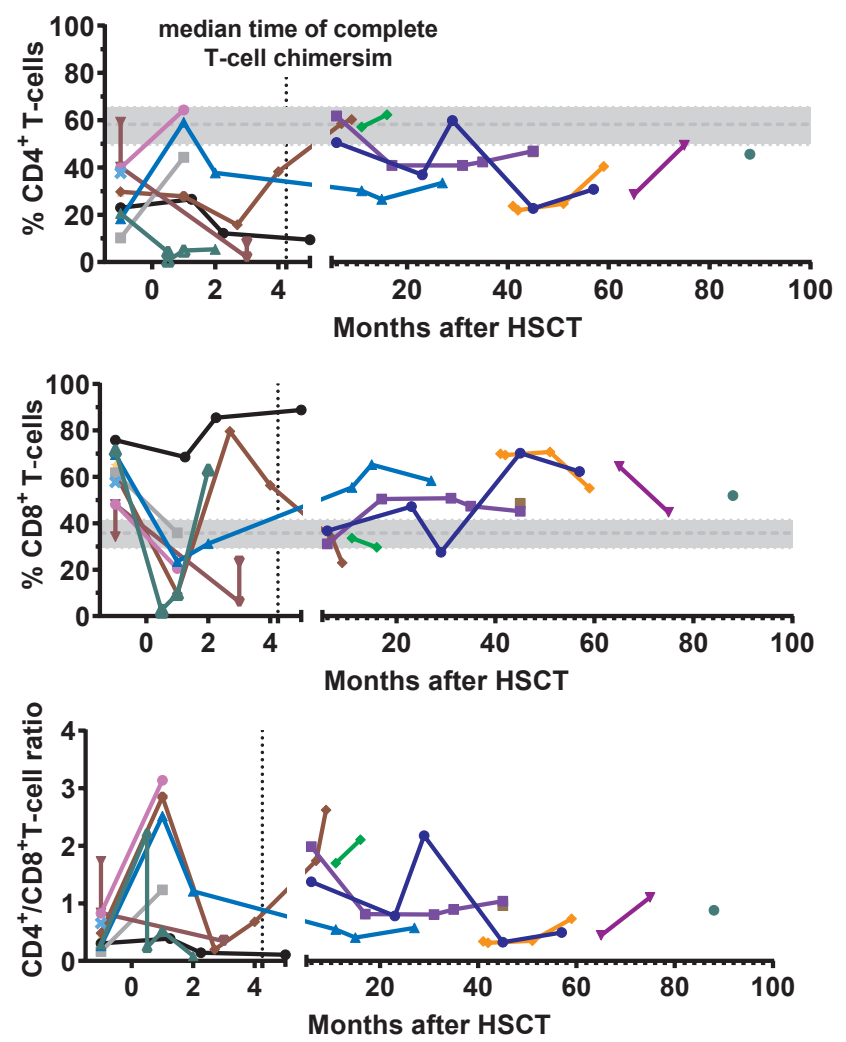

B

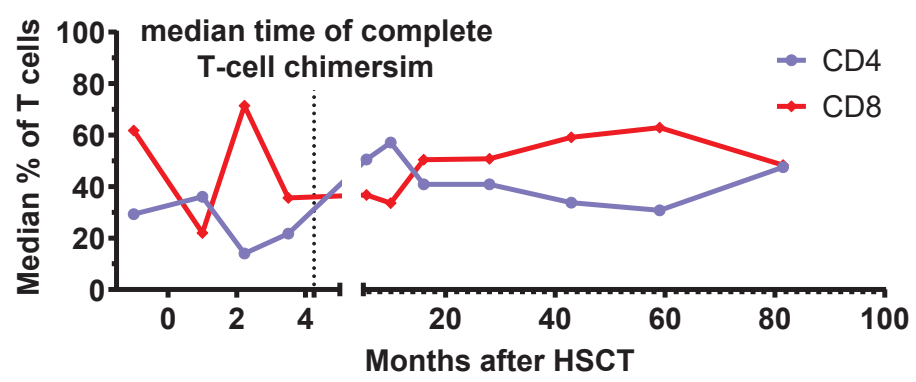

- IciS-03

- IciS-04

- IciS-05

- IciS-06

- IciS-08

- IciS-11

-늘 IciS-12

- IciS-17

- IciS-19

- IciS-20

- IciS-23

- IciS-27

- IciS-28

-IciS-29

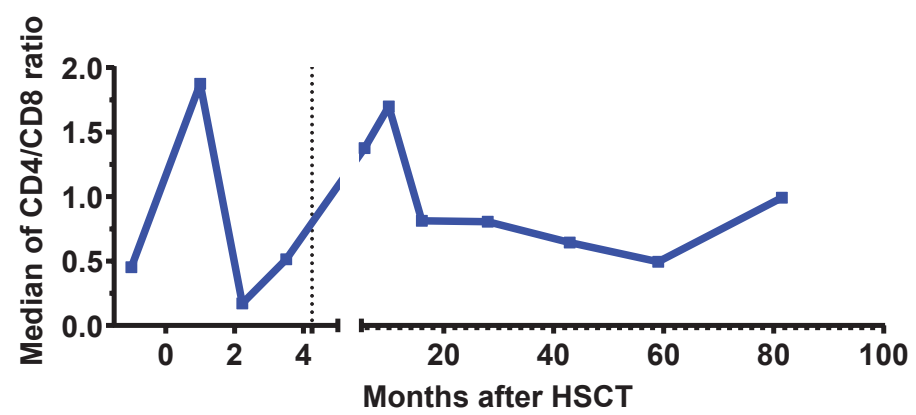

C

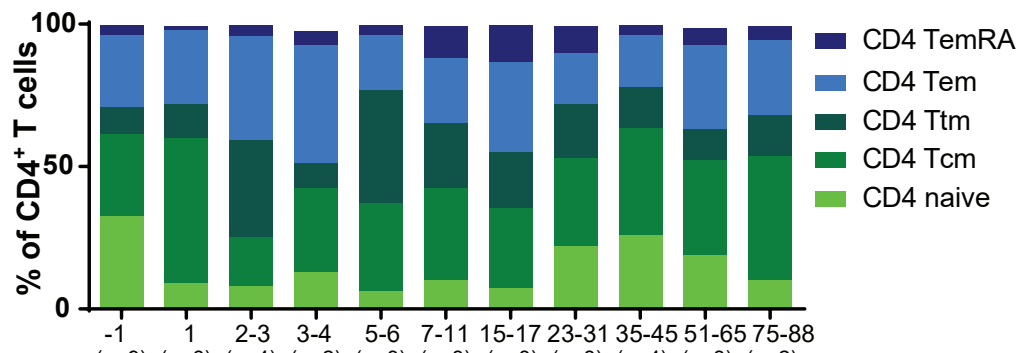
$(n=9) \quad(n=6) \quad(n=4) \quad(n=2) \quad(n=3) \quad(n=3) \quad(n=3) \quad(n=3) \quad(n=4) \quad(n=3) \quad(n=2)$ Month pre/post HSCT

D

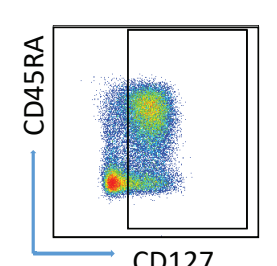

CD127

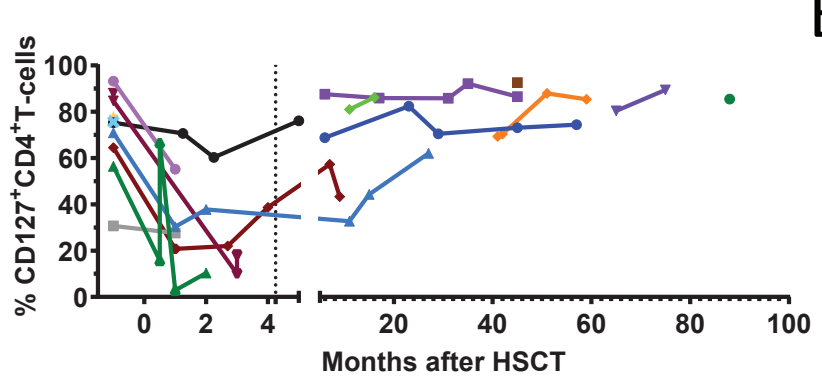

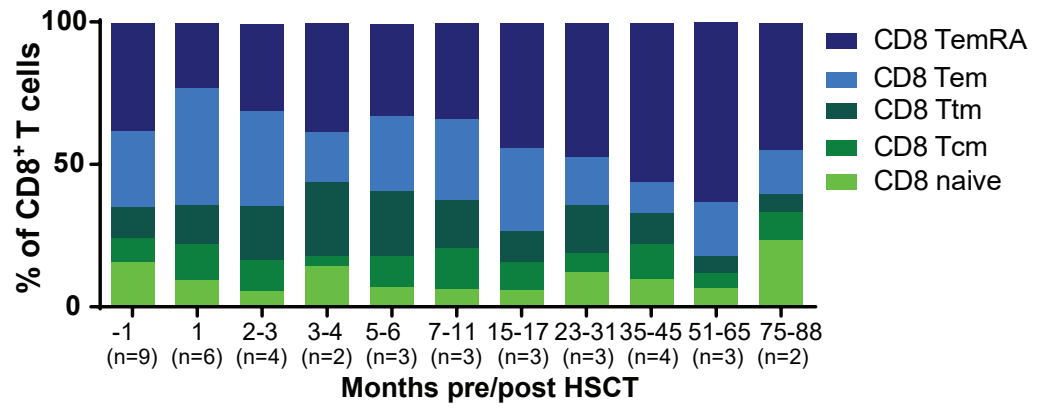

E

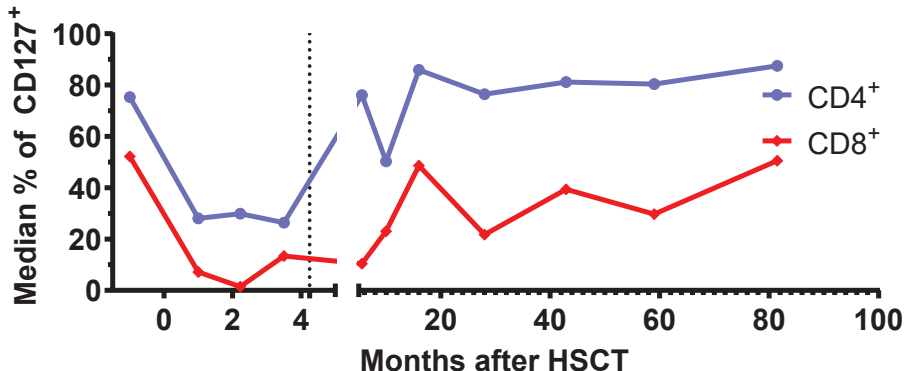

$\rightarrow$ IciS-01 $\rightarrow$ IciS-02- IciS-03-IciS-04- $\rightarrow$ IciS-05-IciS-06- IciS-08 $\rightarrow$ IciS-11

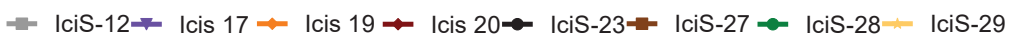
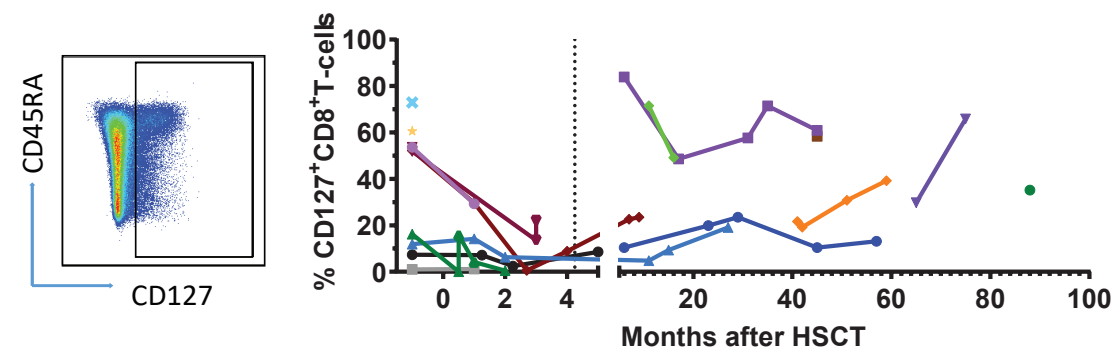
A
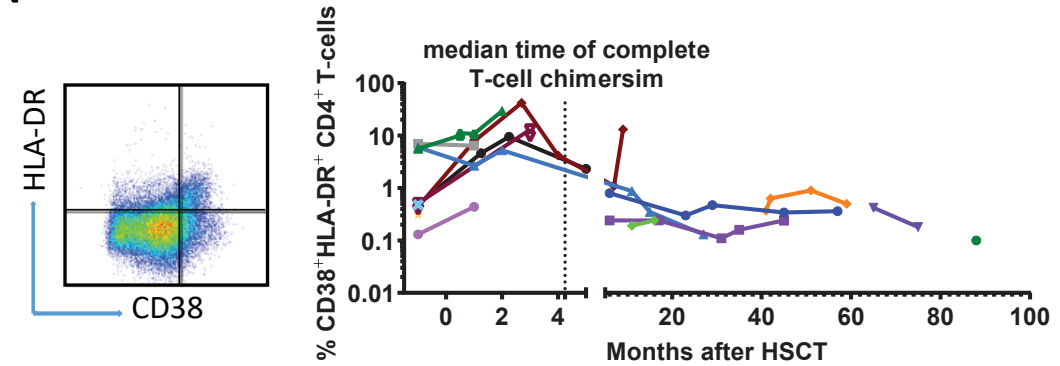

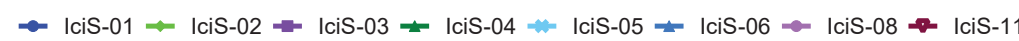

$=$ IciS-12 $\rightarrow$ IciS-17 $\rightarrow$ IciS-19 $\rightarrow$ IciS-20 $\rightarrow$ IciS-23 $\Rightarrow$ IciS-27 $\rightleftharpoons$ IciS-28 $=$ IciS-29

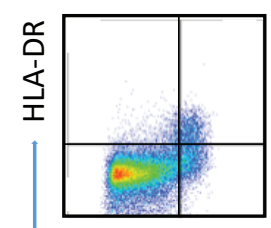

CD38

C

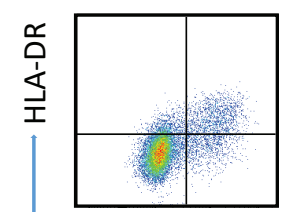

Ki67
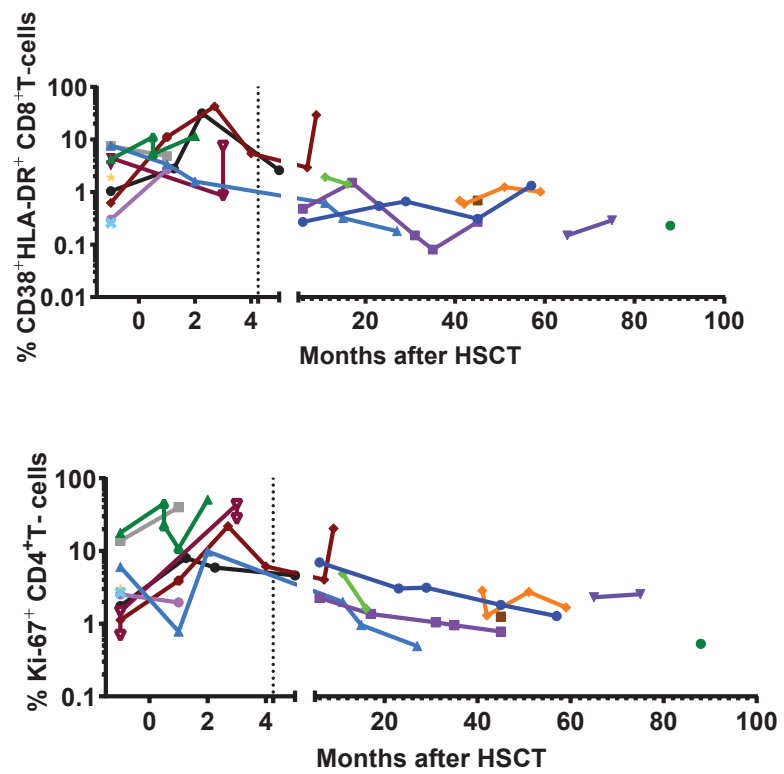

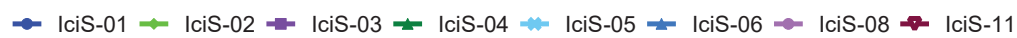

$=$ IciS-12 $\rightarrow$ IciS-17 $\Rightarrow$ IciS-19 $\rightarrow$ IciS-20 $\rightarrow$ IciS-23 $=$ IciS-27 $\Rightarrow$ IciS-28 $\Rightarrow$ IciS-29
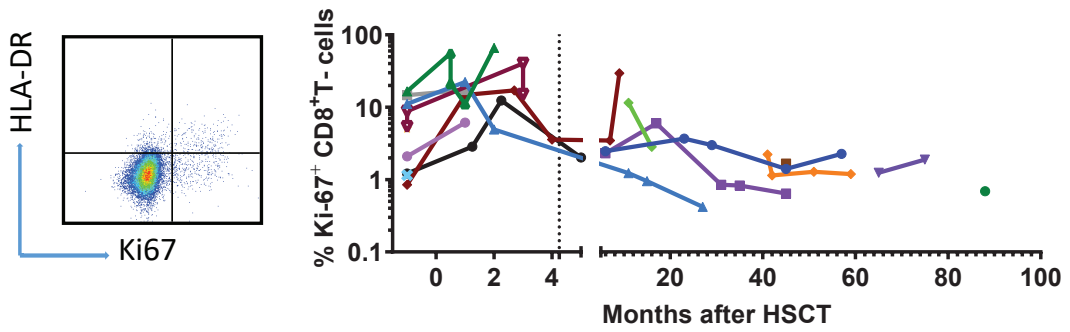

$\mathrm{F}$

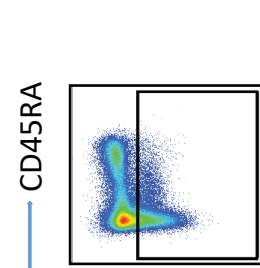

PD-1
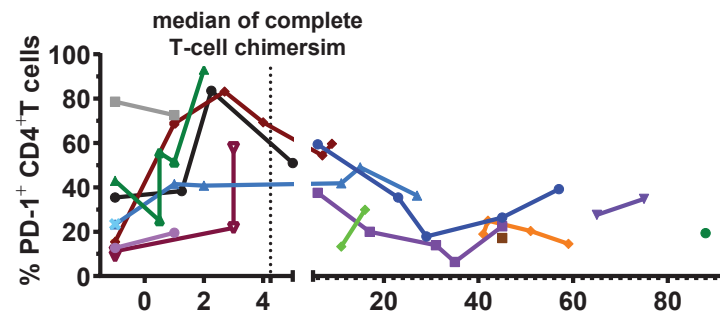

\section{Months after HSCT}

$\rightarrow$ IciS-01 $\rightarrow$ IciS-02 - IciS-03 $\Rightarrow$ IciS-04 $\neq$ IciS-05 - IciS-06 $\rightarrow$ IciS-08 $\rightarrow$ IciS-11 $=\mathrm{IciS}-12+\mathrm{IciS}-17 \rightarrow \mathrm{IciS}-19+\mathrm{IciS}-20 \rightarrow \mathrm{IciS}-23+\mathrm{IciS}-27 \rightarrow \mathrm{IciS}-28+\mathrm{IciS}-29$

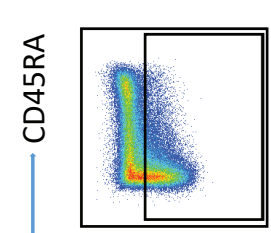

$\rightarrow$ PD-1

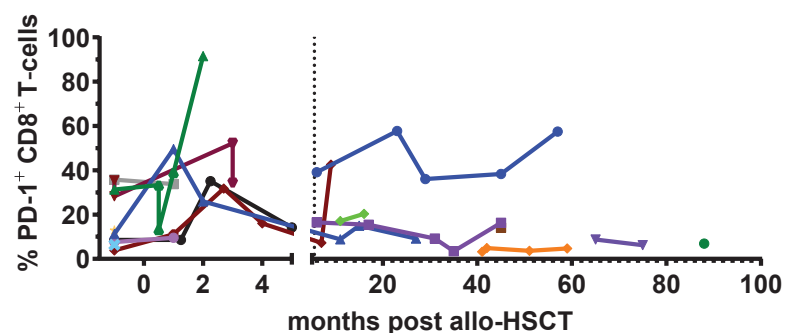

B

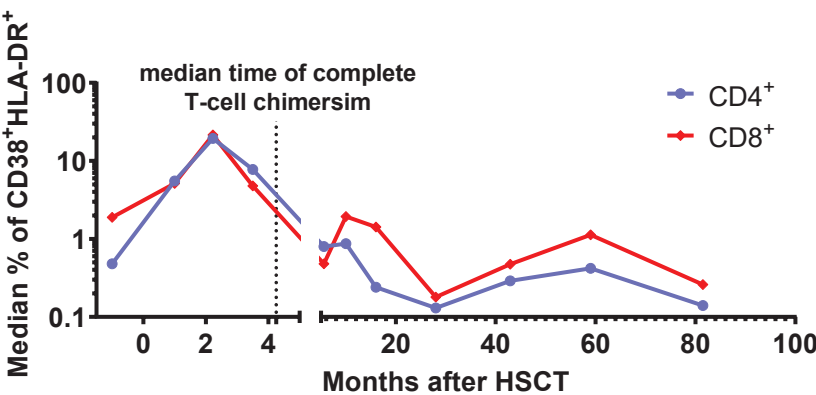

D

E
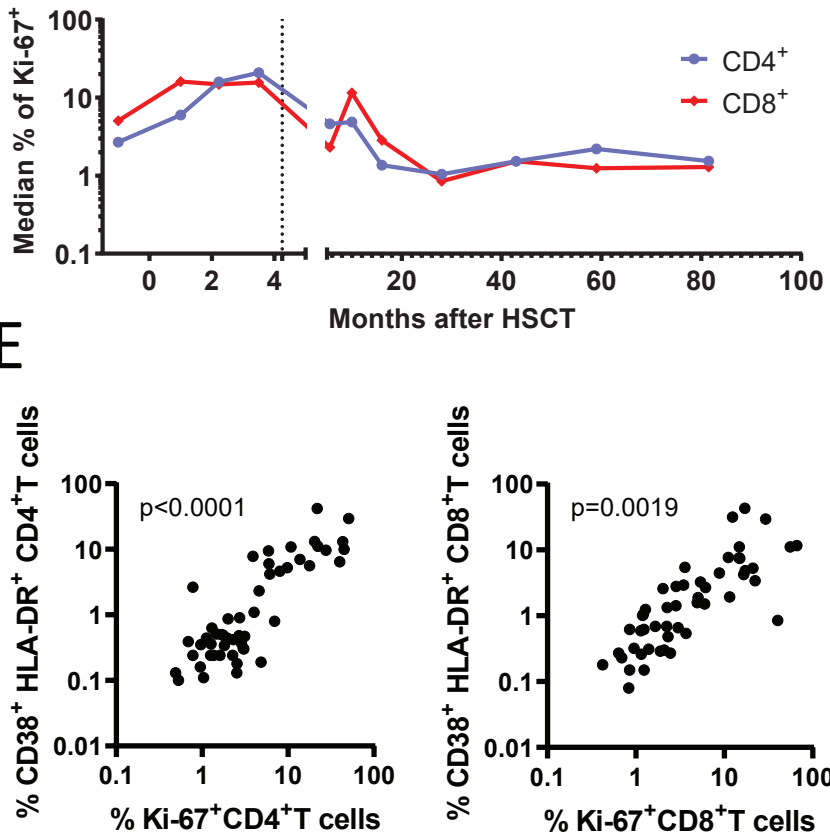

G

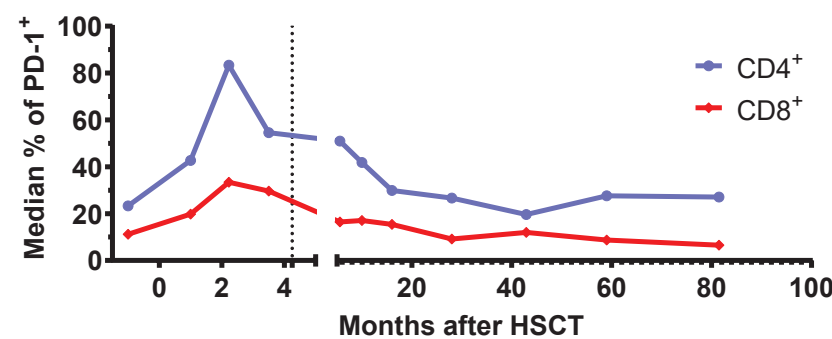


A

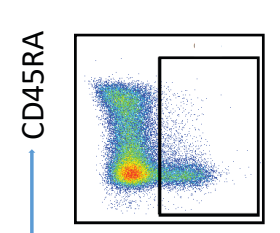

CCR5

B

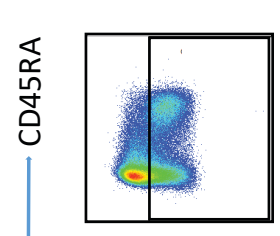

CXCR4

$\mathrm{C}$
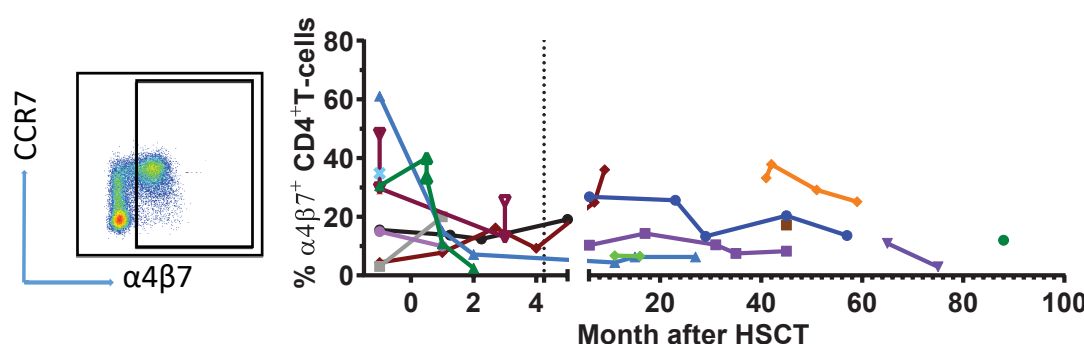

$\rightarrow$ IciS-01 $\Rightarrow$ IciS-02 $\Delta 32 /$ wt $\Rightarrow$ IciS-03 $\Rightarrow$ IciS-06 $\Rightarrow$ IciS-08 $=$ IciS-12 $\rightarrow$ IciS-17 $\rightarrow$ IciS-23 $\rightarrow$ IciS-27 $\rightarrow$ IciS-28 $\div$ IciS-29
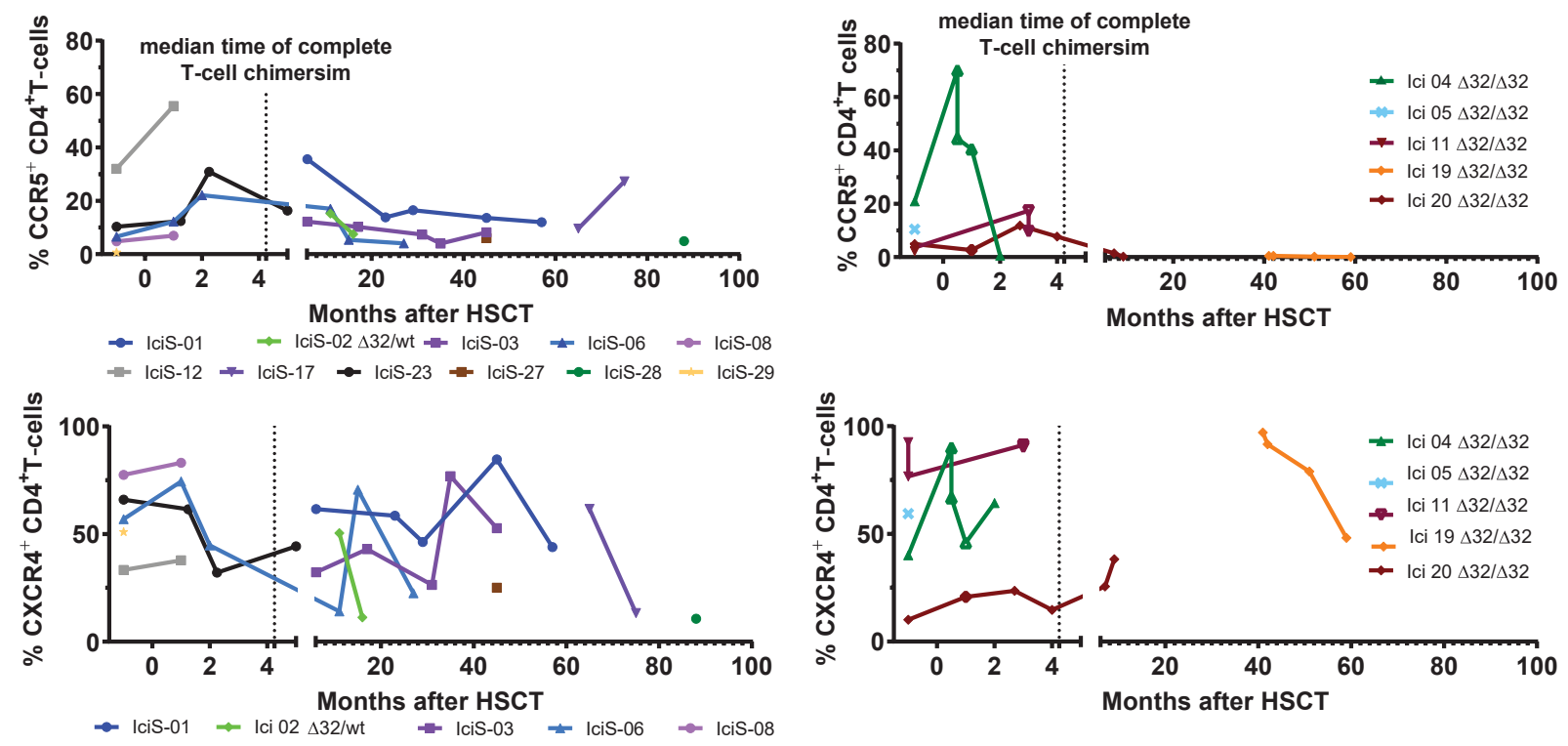

D

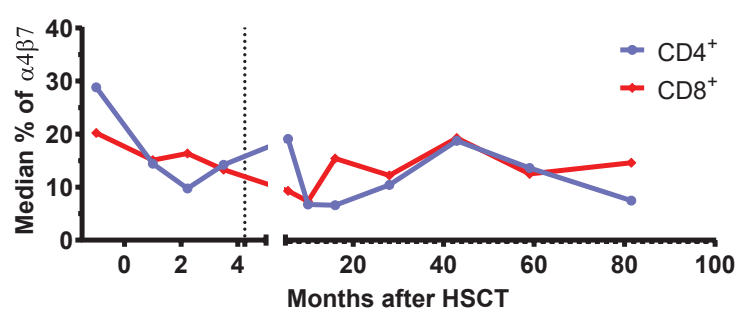

$\rightarrow$ IciS-01 $\rightarrow$ IciS-02 - IciS-03 $=$ IciS-04 $*$ IciS-05 - IciS-06 $\rightarrow$ IciS-08 $\rightarrow$ IciS-11

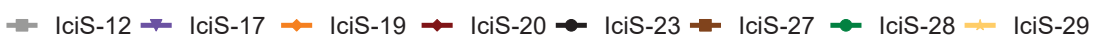
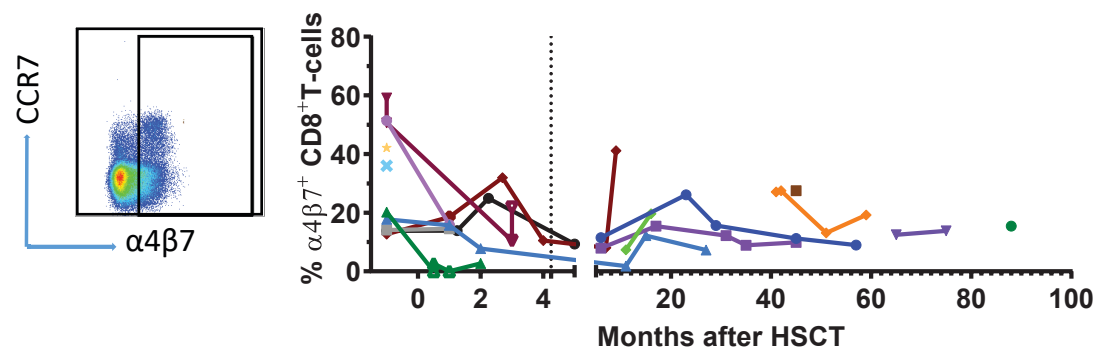
A

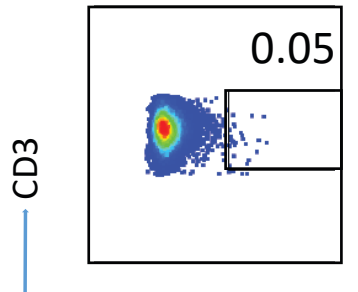

CD107a

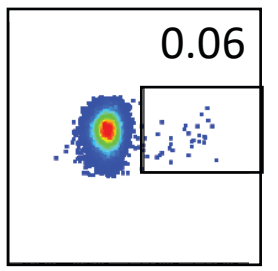

IL2

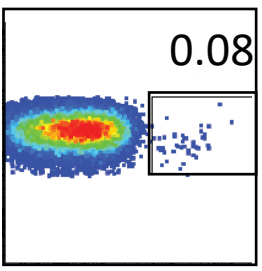

IFN $\gamma$

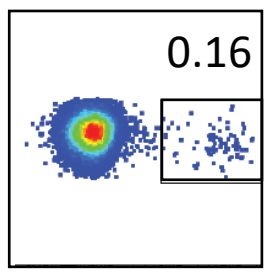

TNF $\alpha$

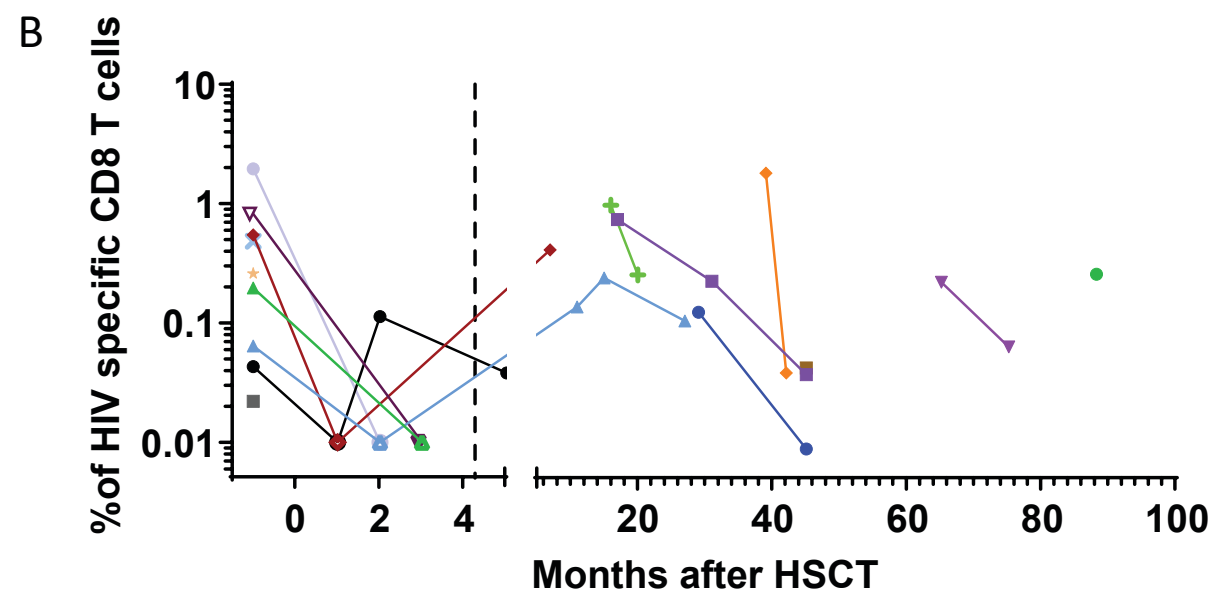

$\rightarrow$ IciS-01 $\rightarrow$ IciS-02 $\rightarrow$ IciS-03 $\rightarrow$ IciS-04 $*$ IciS-05 $\neq$ IciS-06 $\rightarrow$ IciS-08 $\rightarrow$ IciS-11

$\rightarrow \mathrm{IciS}-12 \rightarrow \mathrm{IciS}-17 \rightarrow \mathrm{IciS}-19 \rightarrow \mathrm{IciS}-20 \rightarrow \mathrm{IciS}-23 \rightarrow \mathrm{IciS}-27 \rightarrow \mathrm{IciS}-28 \div \mathrm{IciS}-29$

C
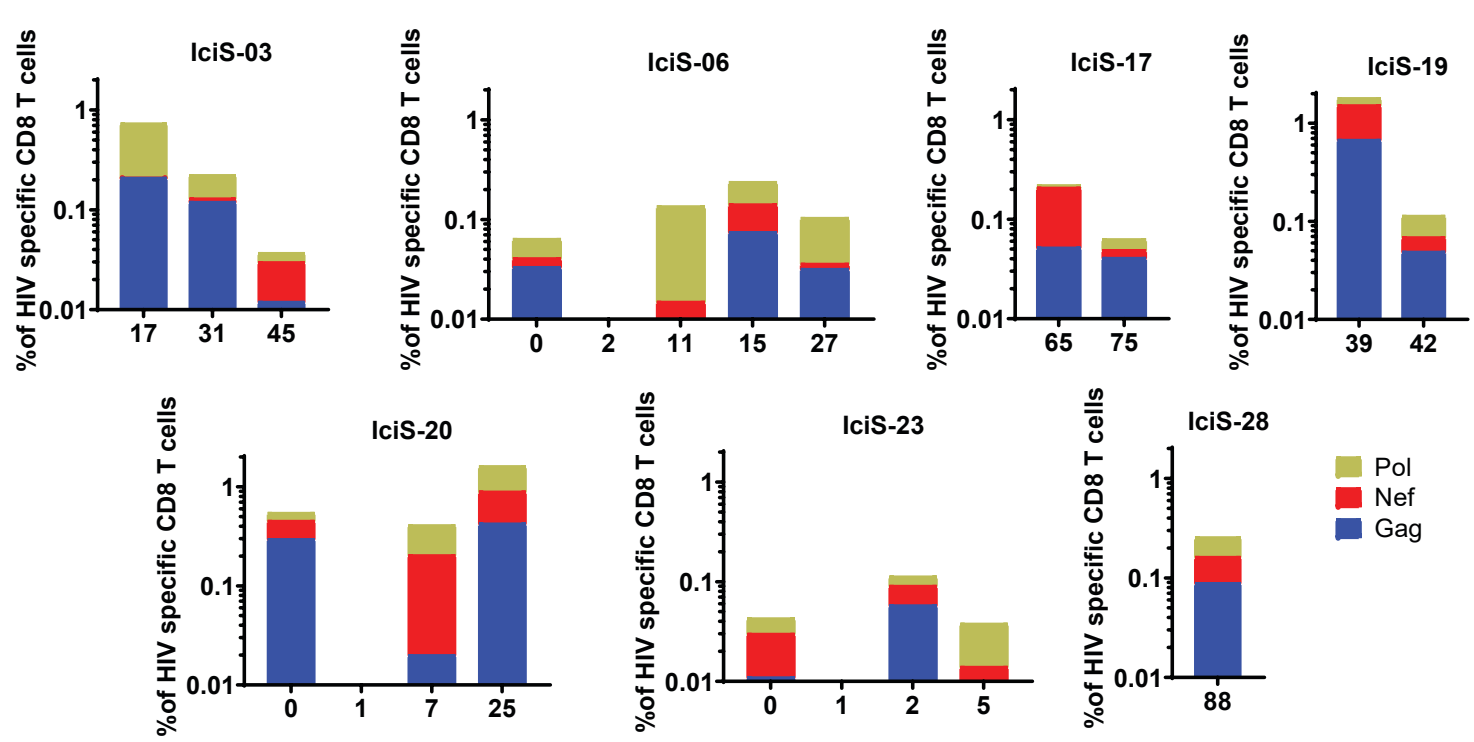

Months after HSCT 
A IciS02/M20 IciS03/M45 IciS06/M27 IciS17/M75 IciS19/M42 IciS20/M7 IciS27/M45 IciS28/M88

HIV
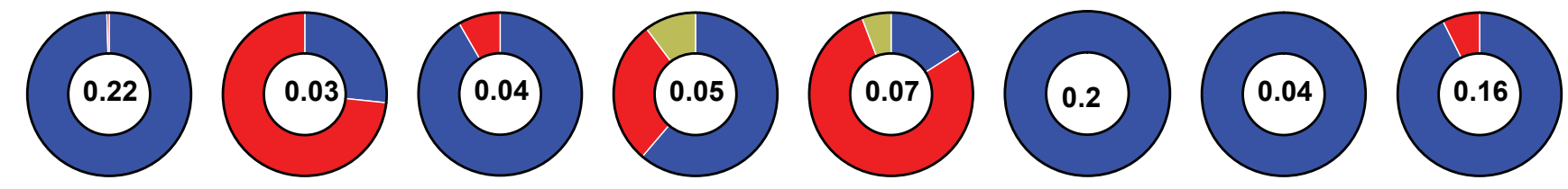

口 2

$\square 4$

CMV
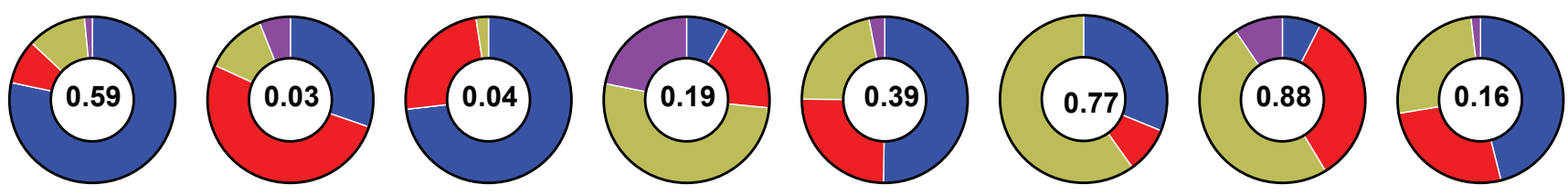

B IciS-23 Baseline M1
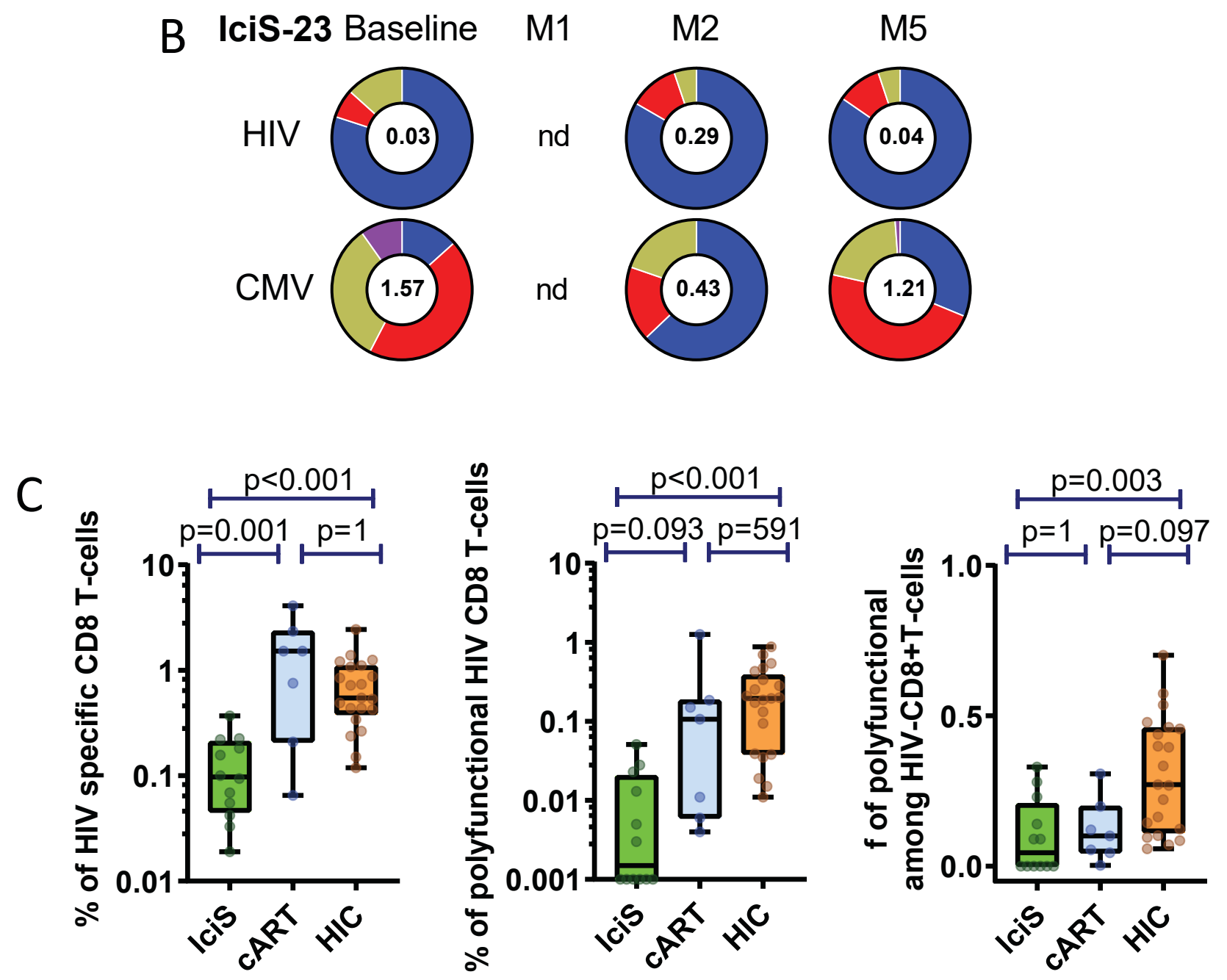


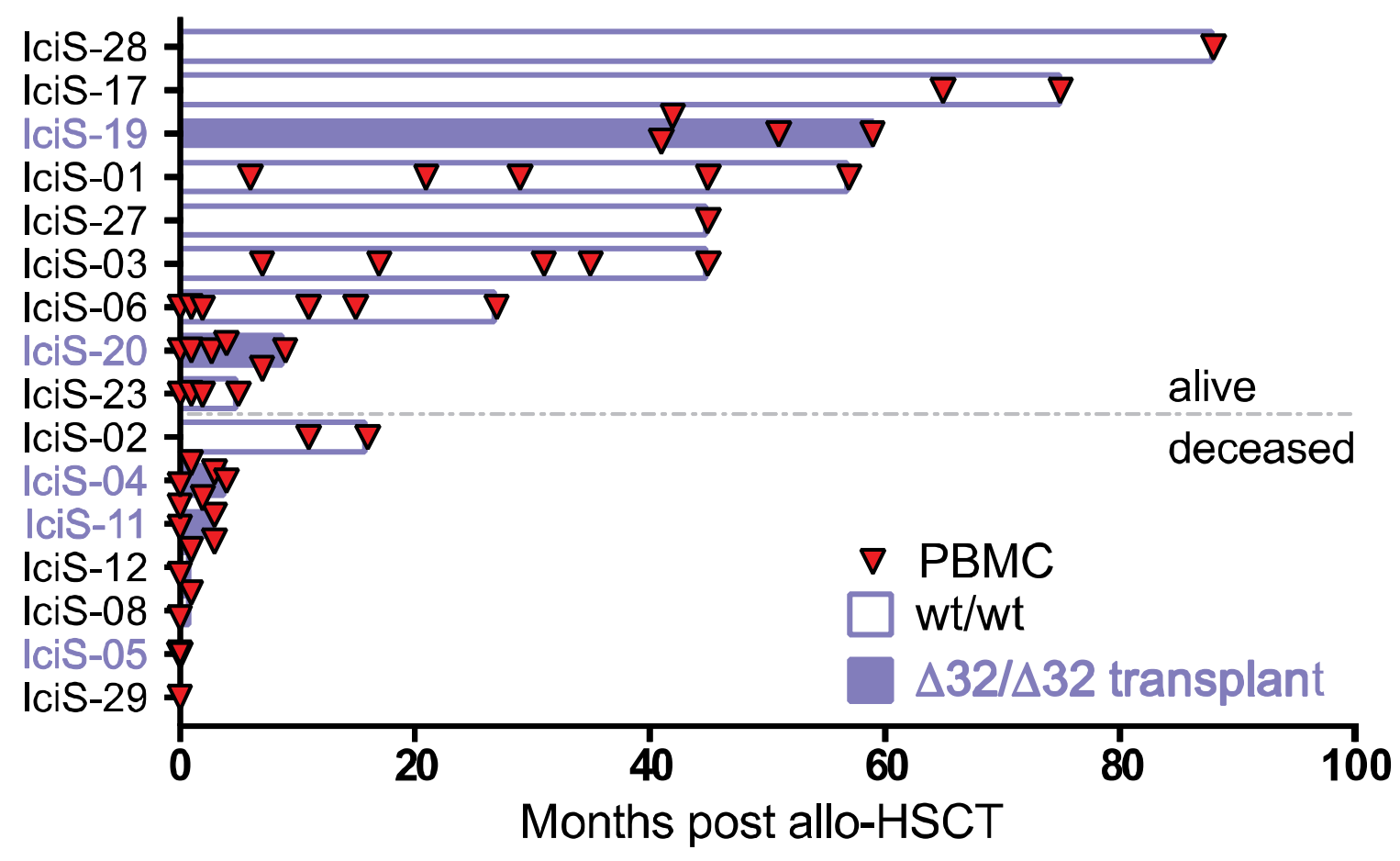

Figure S1: Participant sampling. Bars indicate months of follow-up after allo-HSCT. Red triangles indicate time point of blood draw and PBMC collection. 
A

CD4 ${ }^{+}$T-cells

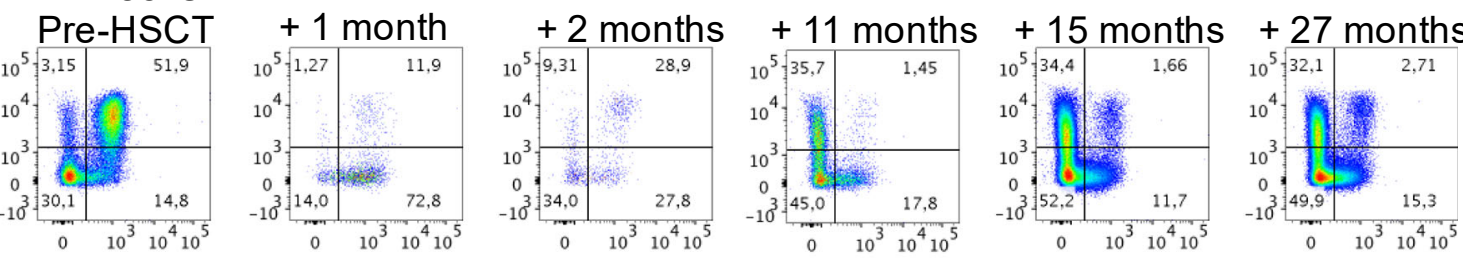

\section{$\mathrm{CD8}^{+} \mathrm{T}$-cells}
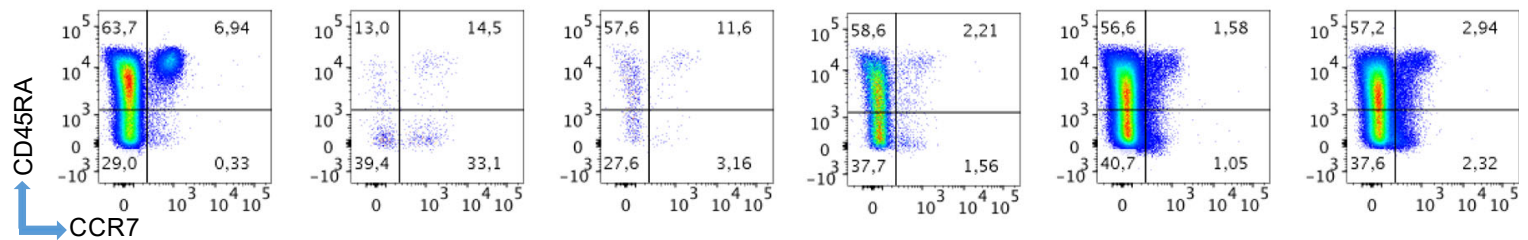

\section{B \\ CD4 ${ }^{+}$T-cells}
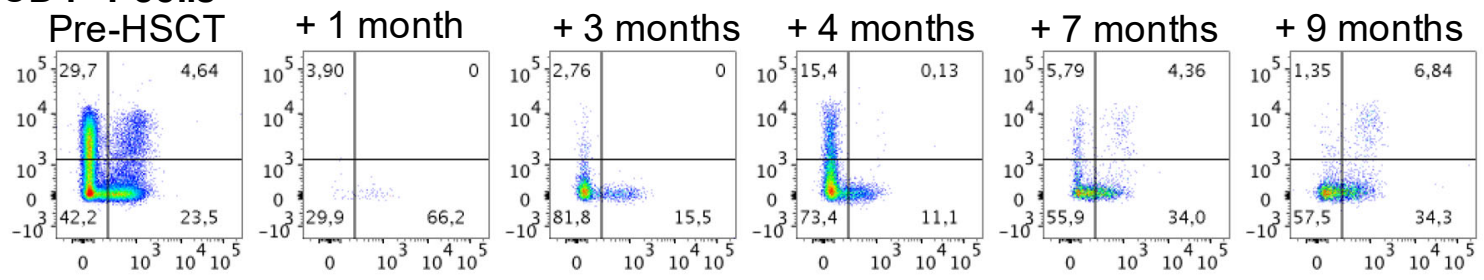

\section{CD8 ${ }^{+}$T-cells}
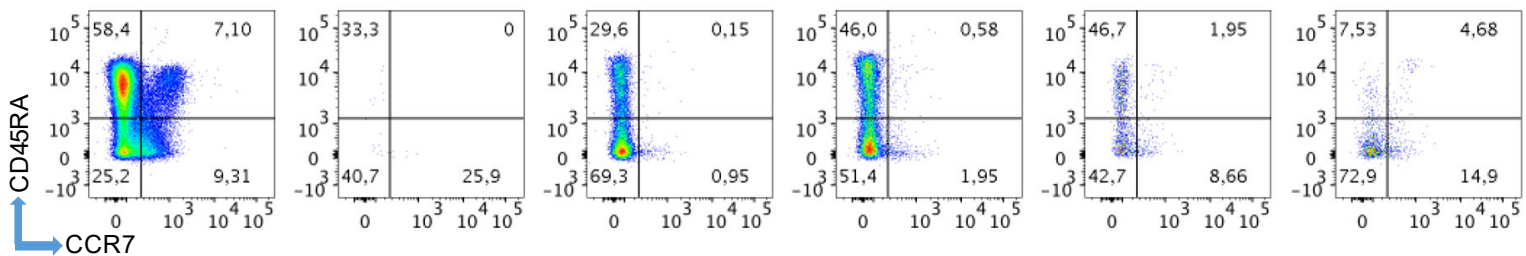

\section{$\mathrm{C}_{\mathrm{CD4}^{+} \text {T-cells }}$}
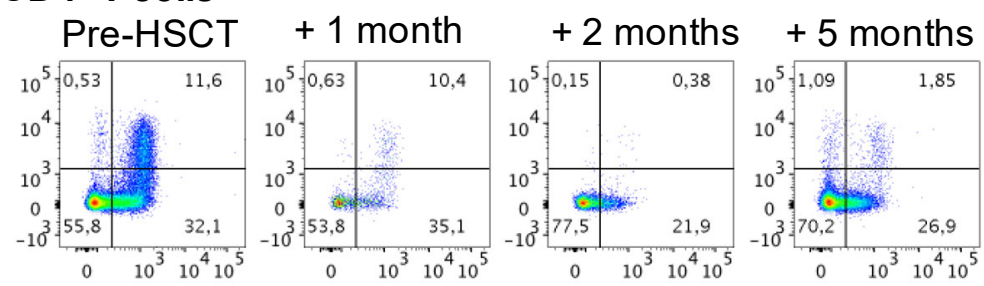

\section{CD8 ${ }^{+}$T-cells}
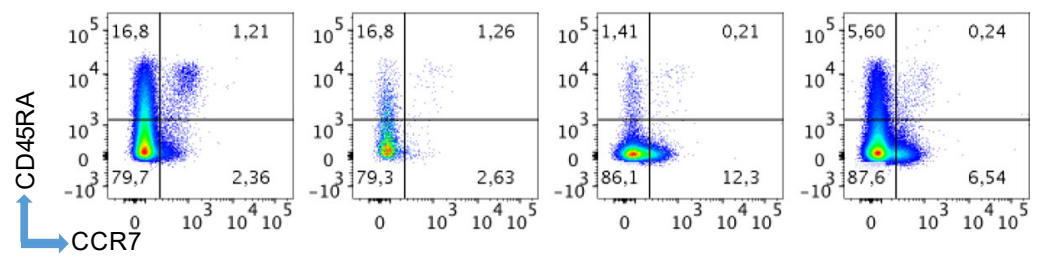
Figure S2: Longitudinal characterization of naïve and memory $\mathrm{CD4}^{+}$and $\mathrm{CD8}^{+} \mathrm{T}$-cell populations for 3 IciStem

participants included in this study. (A)IciS-06, (B) IciS-20, (C) IciS-23. Representative flow cytometry plots showing T-cell memory gating based on CCR7 and CD45RA expression are depicted. 

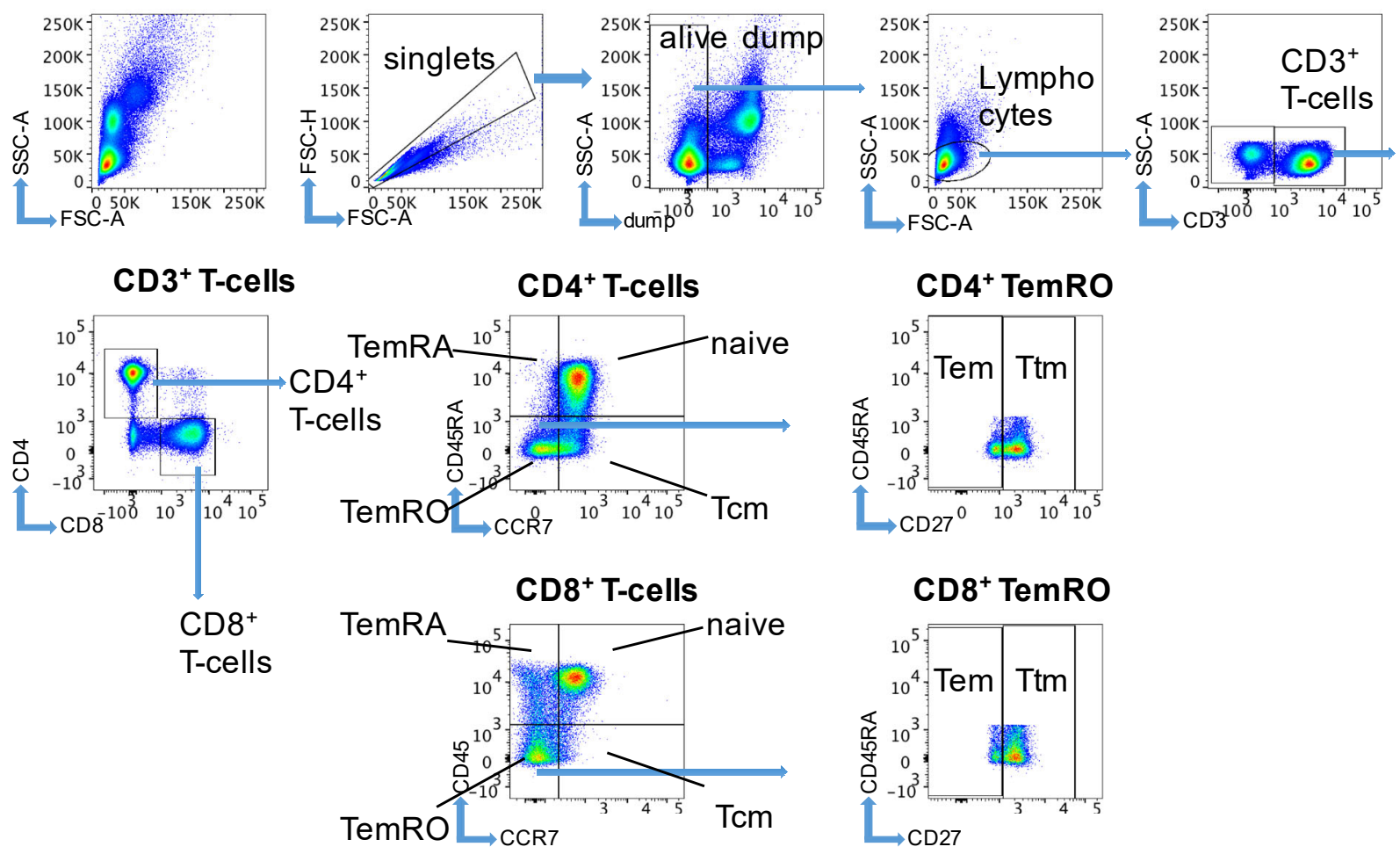

Figure S3: Gating strategy of naïve and memory T-cell populations. Shown are representative flow cytometry plots of a non-infected donor. Bold titles indicate the parent populations, descriptions in the plot indicate the populations that result from the gating. In the "dump", dead cells (Zombie NIR), monocytes (CD14) and B-cells (CD19) were excluded from further analysis. 
A
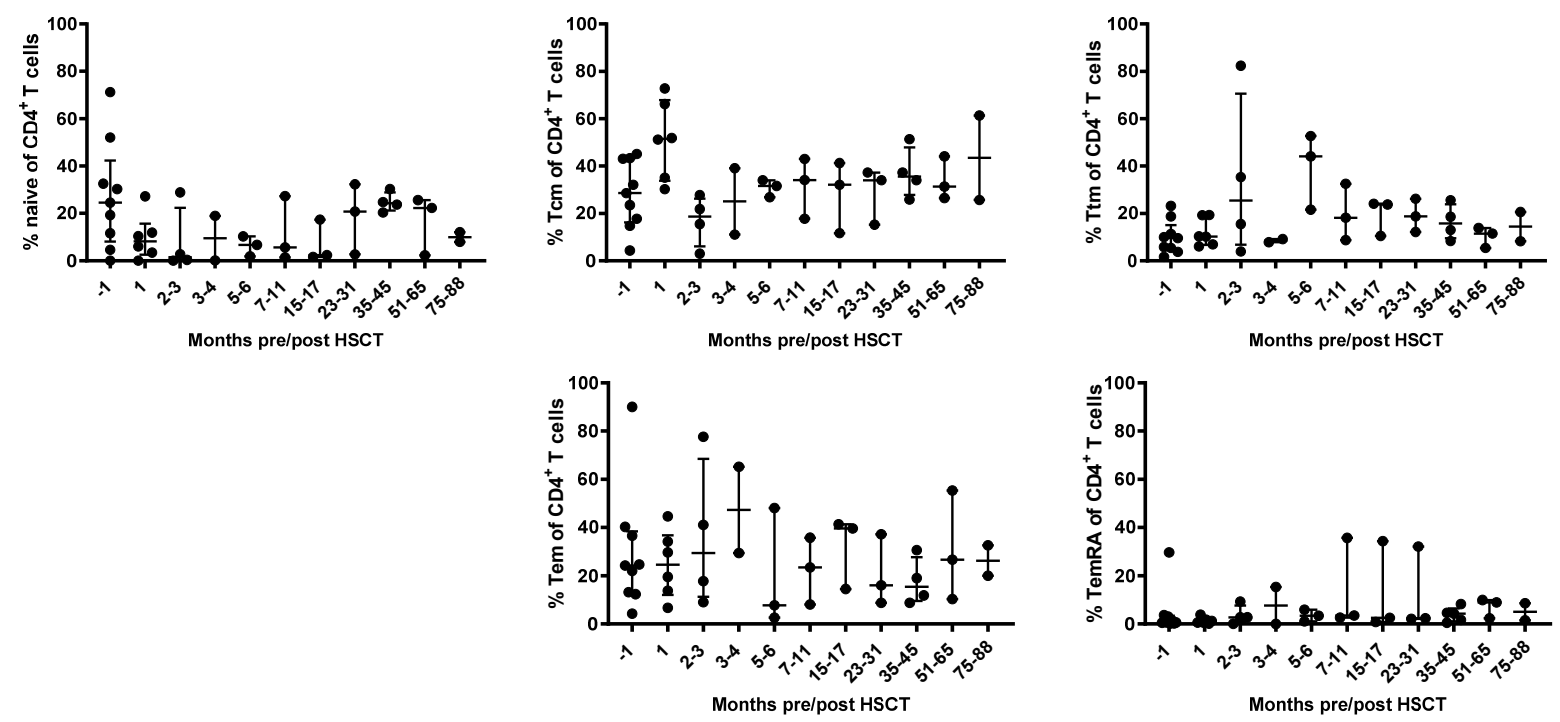

B
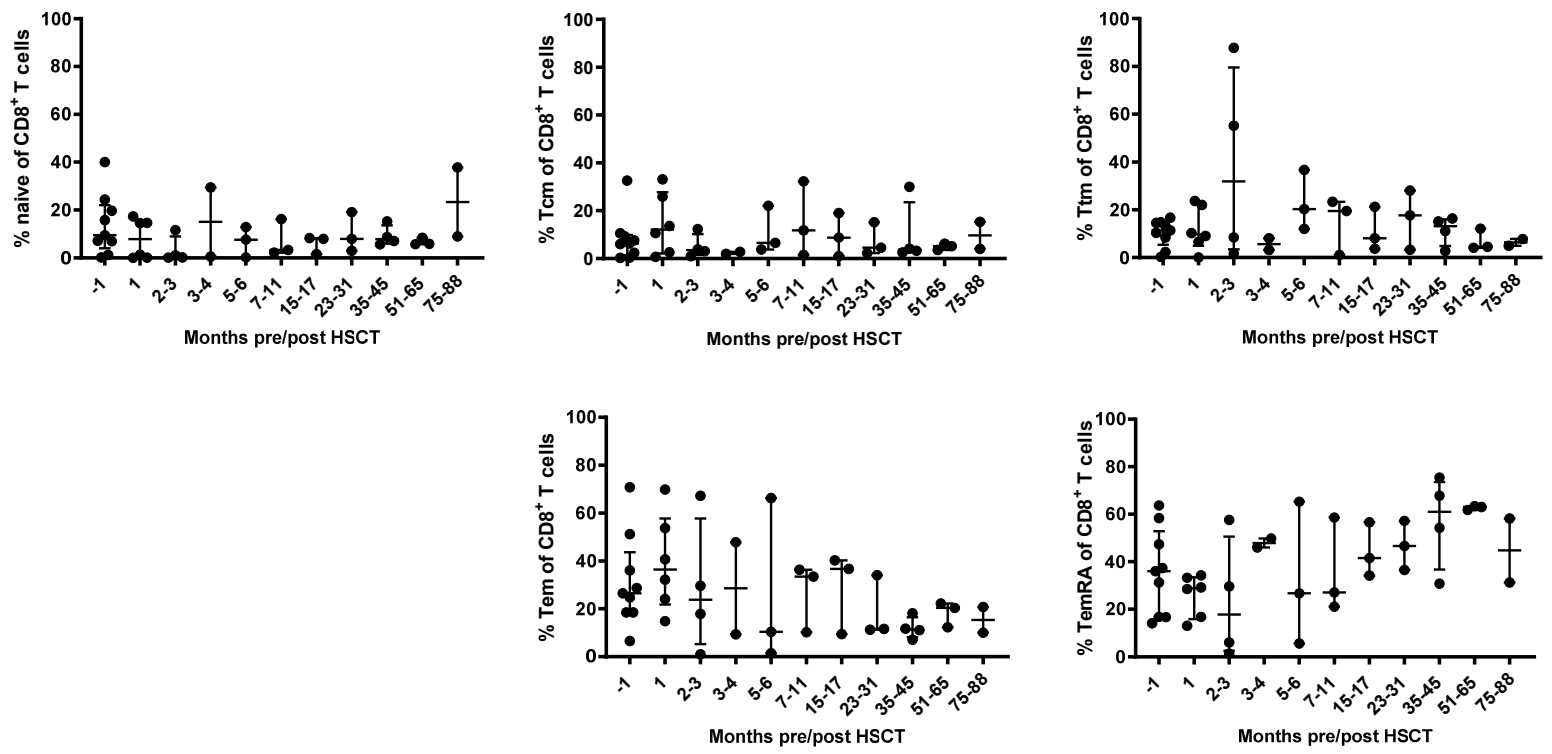

Figure S4: Reconstitution of naïve and memory T-cell populations. (A) $\mathrm{CD} 4^{+}$and (B) $\mathrm{CD} 8^{+} \mathrm{T}$-cell populations.

Shown are medians and IQR for each time period before and after HSCT. Circles represent the T-cell frequency per participant. Means were derived for measurements with more than one data point for each participant within the respective time period. 
A
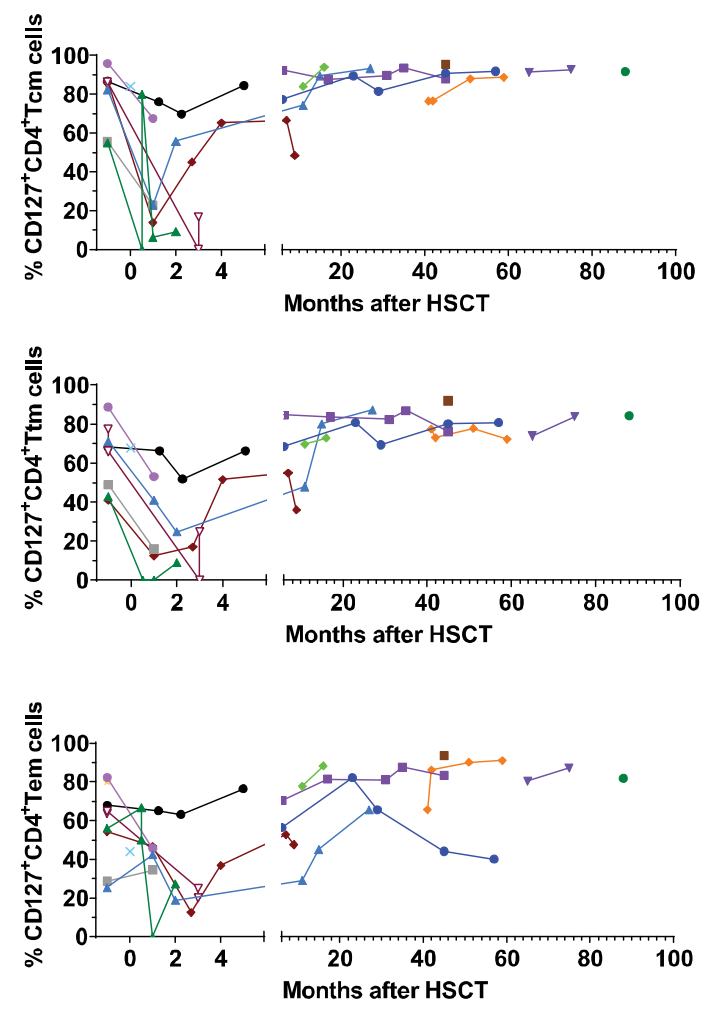

$\rightarrow$ IciS-01 $\rightarrow$ IciS-02 $\rightarrow$ IciS-03 $\rightarrow$ IciS-04

$\rightarrow$ IciS-12 $\rightarrow$ IciS-17 $\rightarrow$ IciS-19 $\rightarrow$ IciS-20
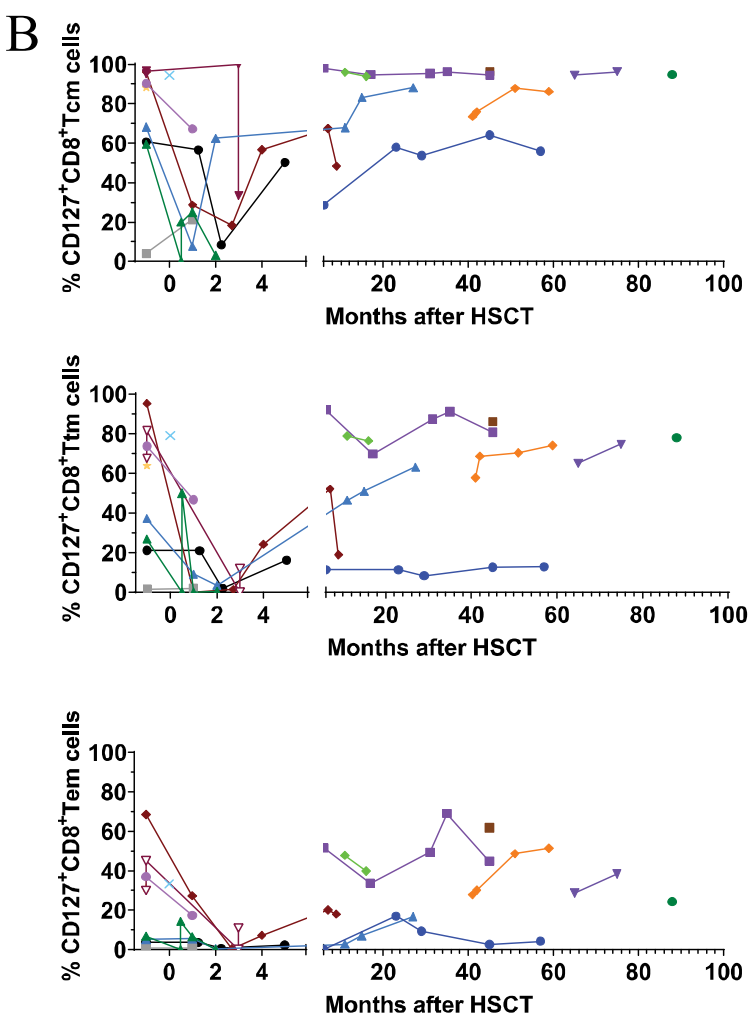

$\mathrm{IciS}-05 \rightarrow \mathrm{IciS}-06 \rightarrow \mathrm{IciS}-08 \rightarrow \mathrm{IciS}-11$

IciS-23 $\rightarrow$ IciS-27 $\rightarrow$ IciS-28 $\div$ IciS-29

Figure S5: CD127 expression on memory T-cells. (A) Frequency of CD127 $\mathrm{CD} 4^{+}$memory and (B) $\mathrm{CD} 127^{+} \mathrm{CD} 8^{+}$ memory T-cells. Symbols and lines represent individual participants over time. 


\section{CCR5 ${ }^{+}$T-cells}
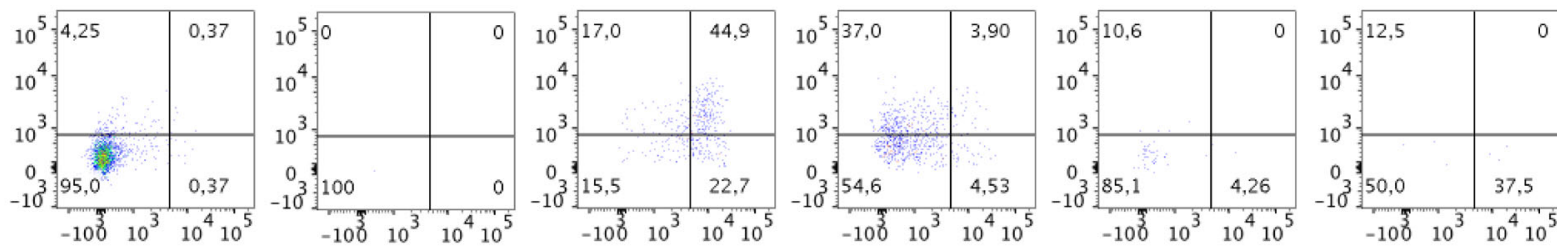

CCR5-T-cells

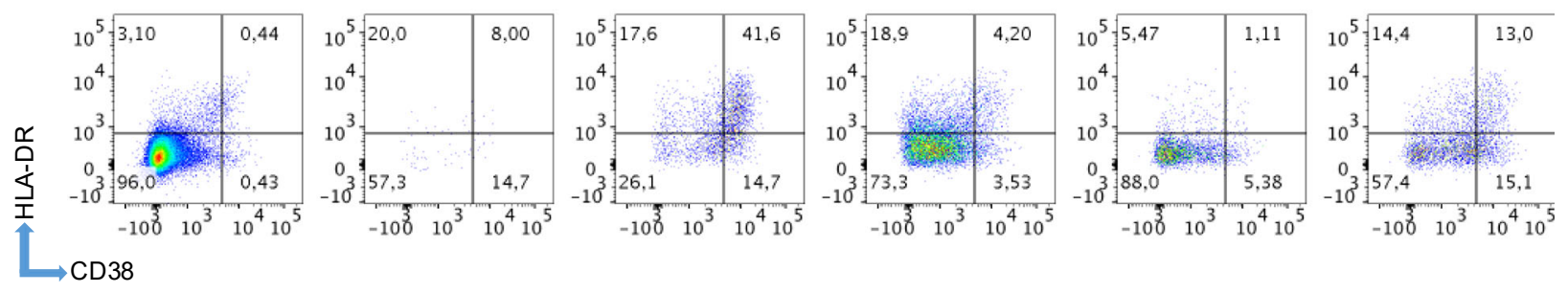

Figure S6: Frequencies of activated $\mathrm{CCR5}^{+}$and $\mathrm{CCR5}^{-} \mathrm{CD4}^{+} \mathrm{T}$-cells during mixed chimerism. Flow cytometry plots depicting HLA-DR and CD38 expression of $\mathrm{CCR}^{+}$and $\mathrm{CCR} 5^{-} \mathrm{CD} 4^{+} \mathrm{T}-$-cells of patient IciS-20. 


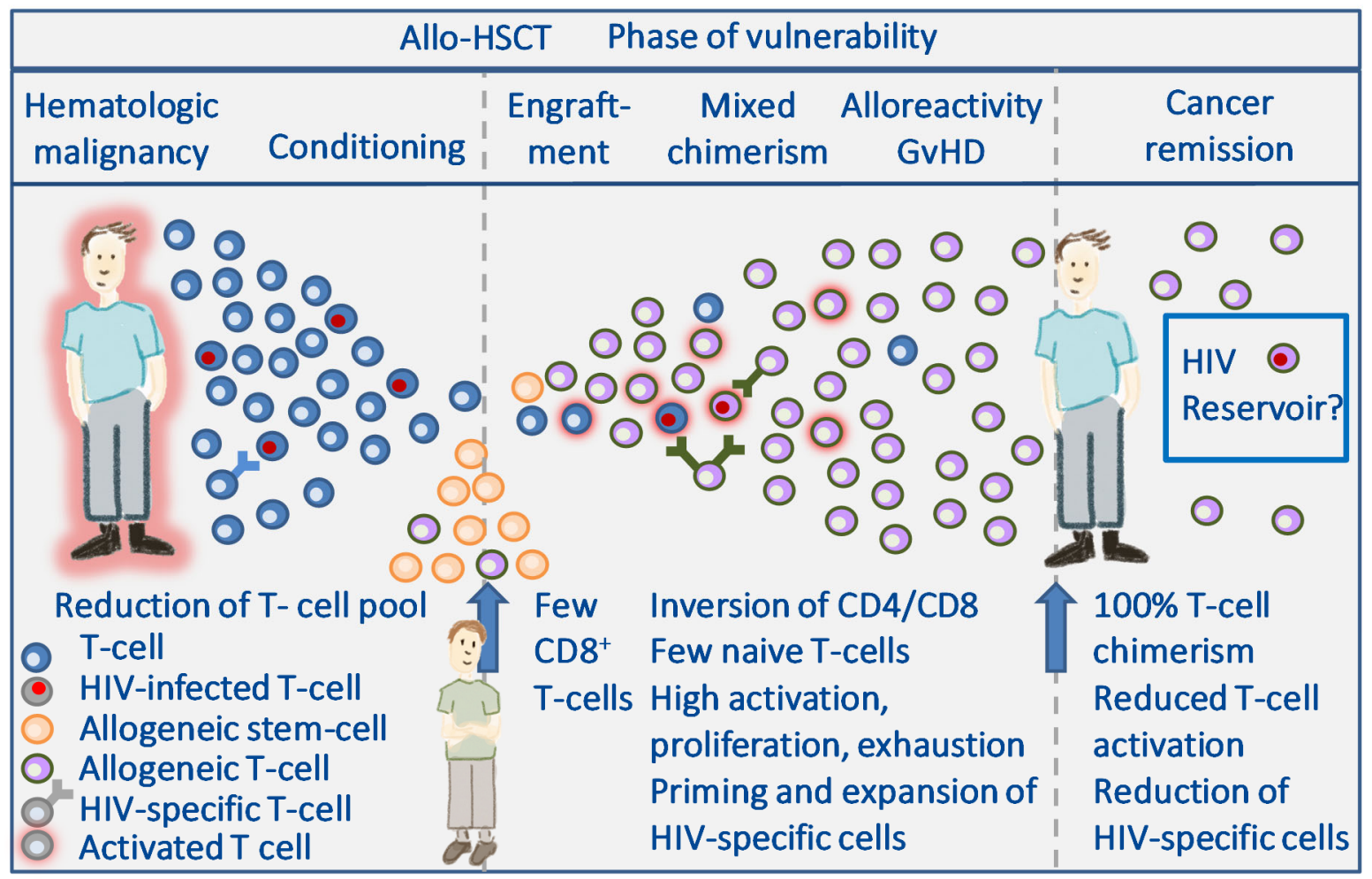

Figure S7: Sequence of hematological events and T-cell reconstitution pre and post allo-HSCT in an HIVinfected cohort. 
Table S1: Virologic characteristics of 16 IciStem participants included in this study

\begin{tabular}{|c|c|c|c|c|c|c|c|}
\hline Patient & $\begin{array}{l}\text { HIV infection } \\
\text { pre-HSCT [years] }\end{array}$ & $\begin{array}{l}\text { ART pre- } \\
\text { HSCT[years] }\end{array}$ & $\begin{array}{l}\text { HIV } \\
\text { tropism }\end{array}$ & $\begin{array}{l}\text { Post-HSCT ART } \\
\text { regimens }\end{array}$ & HIV plasma load [date and copies/ml] & $\begin{array}{l}\text { CMV status of } \\
\text { patient before } \\
\text { HSCT }\end{array}$ & $\begin{array}{l}\text { CMV status of } \\
\text { donor }\end{array}$ \\
\hline IciS-01 & 1 & 1 & R5 & $\begin{array}{c}\mathrm{ABC}+3 \mathrm{TC}+\mathrm{RAL} \\
\mathrm{MVC}\end{array}$ & $\begin{array}{l}\text { month } 29 \text { post-HSCT: } 5 \text { copies } / \mathrm{ml} \text {; month } 45 \text { post- } \\
\text { HSCT: } 3 \text { copies } / \mathrm{ml}\end{array}$ & negative & $\begin{array}{c}\text { Donor 1: not } \\
\text { evaluated Donor 2: } \\
\text { positive }\end{array}$ \\
\hline IciS-02 & 8 months & 8 months & R5 & $\begin{array}{c}\text { 1) } \mathrm{ABC}+3 \mathrm{TC}, \\
\mathrm{MVC} \\
\text { 2) } \mathrm{DRV} / \mathrm{r}, \mathrm{MVC} \\
\text { 3) } \mathrm{DRV} / \mathrm{r} \\
\text { 4) } \mathrm{ABC}+3 \mathrm{TC}, \\
\mathrm{MVC} \\
\text { 5) } \mathrm{ABC}+3 \mathrm{TC} \\
\mathrm{RAL} \\
\text { 6) } \mathrm{ABC}+3 \mathrm{TC} \\
\mathrm{MVC}\end{array}$ & n.a. & positive & Positive \\
\hline IciS-03 & 27 & 19 & $\mathrm{R} 5$ and $\mathrm{X} 4$ & TDF, FTC, RAL & Pre-SCT: $<50$, no detectable usVL post-HSCT & positive & Positive \\
\hline IciS-04 & 4 & n.a. & R5 & $\mathrm{ABC}+3 \mathrm{TC}, \mathrm{RAL}$ & continous viral suppression & n.a. & n.a. \\
\hline IciS-05 & 14 & 14 & R5 & $\begin{array}{l}\text { TDF, FTC, RAL, } \\
\text { MVC, T20, ETR }\end{array}$ & $\begin{array}{l}14 \text { years pre HSCT: } 4800 \text { copies } / \mathrm{ml} \\
2 \text { month post } \mathrm{HSCT}<50 \text { copies } / \mathrm{ml}\end{array}$ & negative & $\begin{array}{l}\text { Donor 1: not } \\
\text { evaluated Donor 2: } \\
\text { positvie }\end{array}$ \\
\hline IciS-06 & 2 & 2 & $\mathrm{R} 5$ and $\mathrm{X} 4$ & TDF, FTC, RAL & Pre-SCT: $<50$, no detectable usVL post-HSCT & positive & Positive \\
\hline IciS-08 & 5 & 7 months & R5 & $\mathrm{DTG}, \mathrm{ABC}+3 \mathrm{TC}$ & n.a. & positive & Positive \\
\hline IciS-11 & 22 & 19 & R5 & $\begin{array}{l}\text { 1) } \mathrm{ABC}+3 \mathrm{TC} \\
\text { DTG } \\
\text { 2) } \mathrm{ABC} \text { substituted } \\
\text { with TDF }\end{array}$ & continuous viral suppression & positive & $\begin{array}{l}\text { Donor 1: positive } \\
\text { Donor 2: negative }\end{array}$ \\
\hline IciS-12 & 2 & 1 & R5 & $\mathrm{ABC}+3 \mathrm{TC}, \mathrm{MVC}$ & n.a. & positive & Positive \\
\hline IciS-17 & 16 & 13 & n.a. & $\begin{array}{l}\mathrm{TDF}, \mathrm{FTC}+\mathrm{DRV} / \mathrm{r} \\
+ \text { RAL }\end{array}$ & $\begin{array}{l}1 \text { month pre-HSCT: } 155 \text { copies } / \mathrm{ml} \\
6 \text { years post-HSCT:0 }\end{array}$ & $\begin{array}{l}\text { IgM negative } \\
\text { IgG positive }\end{array}$ & Positive \\
\hline IciS-19 & $2 \mathrm{y}$ and 4 months & $2 \mathrm{y}$ and 4 months & $\begin{array}{l}\mathrm{R} 5 \\
\text { (minority } \\
\text { X4) }\end{array}$ & $\begin{array}{l}\text { 1) TDF, FTC, RAL } \\
\text { 2) ABC, 3TC, DTG }\end{array}$ & $\begin{array}{c}2 \text { years before HSCT: } 95 \text { copies } / \mathrm{ml} \text { plasma ; a } \\
\text { week later: } 44 \text { copies } / \mathrm{ml} \text { plasma, since then }<50 \\
\text { copies } / \mathrm{ml}\end{array}$ & $\begin{array}{l}\text { IgM negative } \\
\text { IgG positive }\end{array}$ & Positive \\
\hline IciS-20 & 10 & 10 & $\begin{array}{l}\mathrm{R} 5 \\
\text { (minority } \\
\text { X4) }\end{array}$ & $\mathrm{ABC}+3 \mathrm{TC}, \mathrm{DTG}$ & n.a. & n.a. & n.a. \\
\hline IciS-23 & 24 & 12 & $\mathrm{X} 4$ & $\mathrm{ABC}+3 \mathrm{TC}, \mathrm{RAL}$ & $\begin{array}{l}12 \text { years pre-HSCT: }>100000 \\
4 \text { month post-HSCT: }<20\end{array}$ & positive & Negative \\
\hline IciS-27 & 8 & 8 & $\mathrm{X} 4$ & $\begin{array}{c}\text { 1) } \mathrm{TDF}+\mathrm{FTC}+ \\
\mathrm{EFV} \\
\text { 2) } \mathrm{ABC}+3 \mathrm{TC}+ \\
\mathrm{EFV} \\
\text { 3) } \mathrm{ABC}+3 \mathrm{TC} \\
\text { rilpivirine }\end{array}$ & $\begin{array}{l}\text { continuous viral suppression pre-HSCT, last } \\
\text { positive viremia } 6 \text { years before }\end{array}$ & $\begin{array}{l}\text { IgM negative } \\
\text { IgG positive }\end{array}$ & Positive \\
\hline IciS-28 & 11 & 11 & n.a. & $\begin{array}{c}\text { 1) } \mathrm{FTC}+\mathrm{TDF}+ \\
\mathrm{RAL} \\
\text { 2) } \mathrm{ABC}+3 \mathrm{TC}+ \\
\mathrm{RAL} \\
\text { 3) } \mathrm{ABC}+3 \mathrm{TC}+ \\
\mathrm{DTG}\end{array}$ & $\begin{array}{c}\text { continuous viral suppression pre-HSCT, last } \\
\text { positive viremia } 6 \text { years before }(14700 \text { copies } / \mathrm{ml})\end{array}$ & $\begin{array}{l}\text { IgM negative } \\
\text { IgG positive }\end{array}$ & Negative \\
\hline IciS-29 & 6 & 6 & R5 & $\mathrm{ABC}+3 \mathrm{TC}$ & n.a. & positive & Positive \\
\hline
\end{tabular}

3TC = lamivudine; $\mathrm{ABC}=$ abacavir; $\mathrm{ART}=$ antiretroviral therapy $\mathrm{CMV}=$ cytomegalovirus; DRV/r $=$ darunavir + ritonavir; DTG $=$ dolutegravir; $\mathrm{EFV}=$ efavirenz; FLU = fludarabine; FTC = emtricitabine; HSCT = hematopoietic stem cell transplant; MVC = maraviroc; $. \mathrm{a} .=$ not available; $\mathrm{RAL}=$ raltegravir; TDF $=$ tenofovir disoproxil fumarate 
Table S2: HLA-types of 16 IciStem participants included in this study

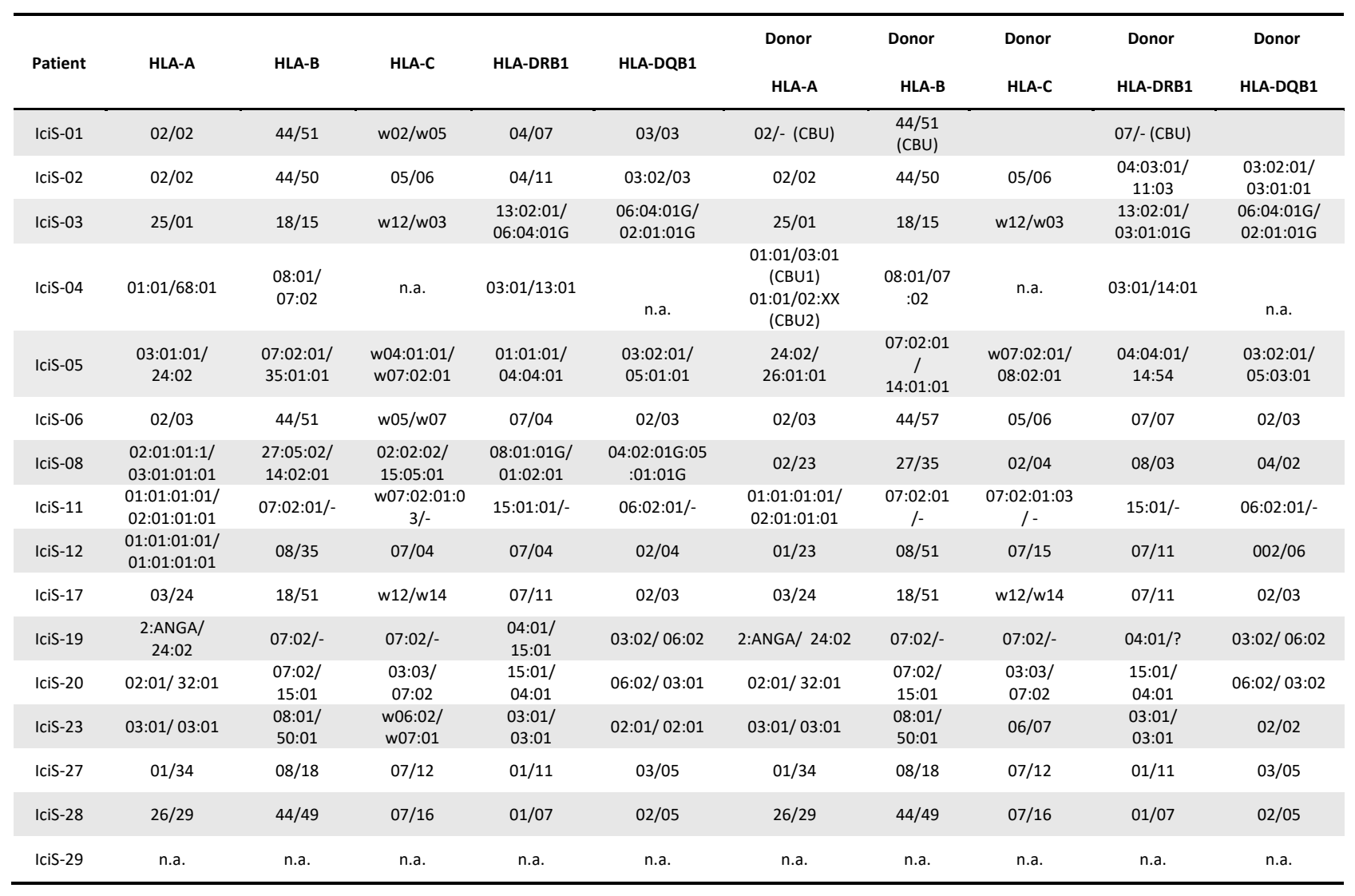

n.a. = not available 
Table S3: Longitudinal CD4 ${ }^{+}$T-cell counts of 16 IciStem participants included in this study

\begin{tabular}{|c|c|c|c|c|c|c|c|}
\hline Patients & $\begin{array}{c}\text { CD4 at start of } \\
\text { ART }\end{array}$ & $\begin{array}{l}\text { Pre-HSCT visit } \\
\text { CD4 cells/ } \mu \mathrm{l}\end{array}$ & $\begin{array}{l}1 \text { month post- } \\
\text { HSCT CD4 } \\
\text { cells/ } / \mu \mathrm{l}\end{array}$ & $\begin{array}{c}\text { 2-3 month post } \\
\text { first HSCT CD4 } \\
\text { cells/ } / \mu \mathrm{I}\end{array}$ & 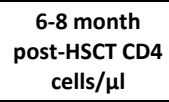 & $\begin{array}{l}\text { 1year post- } \\
\text { HSCT CD4 } \\
\text { cells } / \mu \mathrm{l}\end{array}$ & $\begin{array}{l}\text { Maximum post- } \\
\text { HSCT CD4 } \\
\text { cells/ } / \mu 1\end{array}$ \\
\hline IciS-01 & & 720 & & 55 & & & 891 \\
\hline IciS-02 & & & 1001 & 1512 & 2132 & 918 & \\
\hline IciS-03 & & 800 & 251 & 289 & 381 & & 660 \\
\hline \multicolumn{8}{|l|}{ IciS-04 } \\
\hline IciS-05 & 46 & 392 & 28 (day16) & & & & 28 (day16) \\
\hline Icis-06 & & 151 & & 127 & & 835 & 759 \\
\hline IciS-08 & & & 3 & & & & \\
\hline IciS-11 & 190 & 283 & 21 (day33) & $\begin{array}{c}1 \text { (day } 80 / \text { day } 7 \\
\text { after } 2 \text { nd } \\
\text { transplant) }\end{array}$ & & & 25 \\
\hline \multicolumn{8}{|l|}{ IciS-12 } \\
\hline IciS-17 & unknown & 155 & unknown & 320 & 351 & 688 & 773 \\
\hline IciS-19 & & 750 & & 251 & & & 495 \\
\hline Icis-20 & & 490 & & 142 & & & 415 \\
\hline IciS-23 & 172 & 258 & unknown & 304 & 140 & 362 & 688 \\
\hline IciS-27 & 203 & 747 & & 160 & 394 & 553 & 815 \\
\hline IciS-28 & 45 & 891 & & 390 & & & 2550 \\
\hline Icis-29 & & & & & & & \\
\hline
\end{tabular}

Table S4: Summary of main clinical events observed for IciS-28

\begin{tabular}{lll}
\hline \multicolumn{1}{c}{ Date } & \multicolumn{1}{c}{ Event } & \multicolumn{1}{c}{$\begin{array}{c}\text { Log HIV RNA copies/ml plasma } \\
\text { Median (range) }\end{array}$} \\
\hline 30/Aug/1998 & Primary infection/ART initiation & 5.37 \\
\hline 30/Aug/1998-1/Sept/2018 & ART & $<1.69(<1.28-4.17)$ \\
\hline 15/Oct/2005 & Hodgkin Lymphoma (Stage III) & $<1.28$ \\
\hline 14/May/2008 & Autologous HSCT & $<1.69$ \\
\hline 10/Sept/2009 & Allogeneic HCST & $<1.69$ \\
\hline 1/Sept/2018 & ART discontinuation & $<1.69$ \\
\hline 20/Jan/2019 & Viral rebound & 5 \\
\hline
\end{tabular}

